\title{
Cross-Country Relative Price Volatility: EFFECTS OF MARKET STRUCTURE
}

\author{
YIN-WONG CHEUNG \\ EIJI FUJII
}

\author{
CESIFO WORKING PAPER NO. 1456 \\ CATEGORY 6: MONETARY POLICY AND INTERNATIONAL FINANCE \\ APRIL 2005
}

An electronic version of the paper may be downloaded

- from the SSRN website:

www.SSRN.com

- from the CESifo website:

www.CESifo.de 


\title{
CROSS-COUNTRY Relative PRICE VOLATILITY: EFFECTS OF MARKET STRUCTURE
}

\begin{abstract}
Using annual data on nine manufacturing sectors of eighteen OECD countries, the article studies the implications of market structure for cross-country relative price variability. It is found that, in accordance with predictions from a standard markup pricing model, reductions in market competition, along with increased nominal exchange rate volatility, are associated with greater variability of cross-country relative prices. The market structure also has similar effects on components of cross-country relative price variability. The empirical findings are robust to the inclusion of various control variables and alternative sample specifications.

Abstract
\end{abstract}

JEL Code: F31, F41.

Keywords: relative price volatility, market structure, price-cost margin, variance decomposition.

Yin-Wong Cheung
Department of Economics, SS1
University of California
Santa Cruz, CA 95064
USA
cheung@ucsc.edu

Yin-Wong Cheung

University of California

cheung@ucsc.edu

(20composition.

(1) 


\section{Introduction}

Considerable efforts have been devoted to examine cross-country exchange-rate-adjusted relative price (which, for brevity, is labeled cross-country relative price hereafter) fluctuations and their determinants. Engel (1993, 1999), for instance, demonstrate that the main determinant of real exchange rate variability is the relative price movement between similar goods, rather than between traded and non-traded goods, across countries. Using the US and Canadian city data, Engel and Rogers (1996) find that volatilities of relative prices of similar goods and services are significantly amplified when markets are separated by a national border. Their results indicate that the magnitude of the cross-border effect is far beyond what the physical distance between the U.S. and the Canadian cities can explain - a result indicative of market segmentation and the violation of the law of one price. ${ }^{1}$

Volatile-nominal-exchange-rate-cum-sticky-price is one factor commonly emphasized by some recent studies on cross-country relative price variability. When local prices are sticky, higher nominal exchange rate volatility will lead to higher cross-country relative price variability. For instance, Engel and Rogers (1996) assess that the volatile-nominal-exchange-rate-cum-stickyprice effect can account for $10 \%$ to $15 \%$ of the total cross-border relative price variation. In addition to volatile-nominal-exchange-rate-cum-sticky-price, unit shipping costs, (formal and informal) trade barriers, and relative wage variability are considered determining factors in studies of cross-border relative price variability (Engel and Rogers, 2001; Parsley and Wei, 2001).

One potential source of cross-country relative price volatility is the price setting behavior under an imperfectly competitive market structure (Engel and Rogers, 1996, 2000). Specifically, prices are determined by, among other factors, price markups under imperfect competition. Prices

1. Violations of the law of one price are reported in, for example, Isard (1977) and Haskel and Wolf (2001). Goldberg and Verboven (2001), on the other hand, use a panel data on car prices in Europe and report strong evidence of convergence toward the law of one price as a result of market integration. 
can vary when markups change. Thus, the market structure, which affects markup behavior, can affect prices and, hence, impact cross-country relative price fluctuations.

In this study, we investigate the implications of market structure for cross-country relative price volatility. Annual data on nine manufacturing sectors from eighteen OECD countries are used to explore the role of market competitiveness. The sample of sectors across various countries is expected to display a diverse market structure profile that allows us to reveal the effects of market competitiveness on pricing behavior and, hence, cross-country relative price variation. A markup pricing model is used to motivate the choices of empirical market structure variables. Specifically, the price-cost margin is adopted as a proxy for the degree of monopolistic pricing power. In addition to cross-country relative price volatility itself, we examine the effects of market structure on its components.

The current exercise can be viewed as a companion piece to Cheung, Chinn and Fujii (2001), who find the persistence of deviations from purchasing power parity is affected by the degree of market competitiveness. In this exercise, however, we examine market structure effects on the volatility of cross-country relative prices. The current exercise should complement their study and shed additional light on cross-country relative price dynamics.

The remainder of this manuscript is organized as follows. Section 2 describes the data. Section 3 presents a markup pricing model that illustrates the role of market competitiveness. Section 4 describes the proxies for market competitiveness and reports the empirical evidence of market structure effects on cross-country relative price variability and on its components. Some robustness analysis results are also discussed. A summary is provided in section 5.

\section{Data}

In this study, we examine annual data on nine manufacturing sectors of eighteen OECD 
countries. The sample period is from 1970 to 1994 . The sector and country coverage is determined by data availability. The nine sectors (two-digit International Standard Industrial Classification (ISIC) Revision 2 codes in parentheses) are: food (31); textiles, apparel, and leather (32); wood products and furniture (33); paper, paper products, and printing (34); chemical products (35); non-metallic mineral products (36); basic metal industries (37); fabricated metal industries (38); and other manufacturing (39). ${ }^{2}$ The country sample consists of Australia, Austria, Belgium, Canada, Denmark, Finland, France, Germany, Greece, Italy, Japan, the Netherlands, Norway, Portugal, Spain, Sweden, the United Kingdom, and the US. The countries are drawn from North America and Europe as well as Scandinavia, Asia, and Oceania, creating a geographically and culturally diverse sample.

The OECD International Sectoral Database contains data on gross output, value added in gross output, and labor compensation. Data on the value added in current and 1990-constant prices are used to construct sectoral price indexes. Annual U.S. dollar exchange rates obtained from the International Financial Statistics are used to compute all the bilateral exchange rates. The great circle distance between national capitals is used as a proxy for the distance between countries.

\section{Market Structure and Relative Price Variability}

The potential effect of market structure on cross-country relative price volatility can be illustrated using a standard markup pricing formulation. For instance, the price of sector $k$ in country $i$ at time $t, p_{i, t}^{k}$, can be written as (Engel and Rogers, 1996; 2000):

$$
p_{i, t}^{k}=\mu_{i, t}^{k}+\tau w_{i, t}^{k}+(1-\tau) m_{i, t}^{k},
$$

2. Lately, the OECD has updated the industry classification codes from ISIC Revision 2 to ISIC Revision 3. The effective sample period under the ISIC Revision 3 scheme is rather short for many countries due to missing observations. Thus, we work with the data based on the Revision 2 codes. Results pertaining to data based on the Revision 3 classification are discussed in Section 4d. 
where $\mu_{i, t}^{k}$ is the monopolistic markup, $w_{i, t}^{k}$ is the cost of the non-traded service, $m_{i, t}^{k}$ is the cost of traded input, and $\tau$ is the share of the non-traded component in the total costs. All terms except $\tau$ are in logarithms. Similarly, the price of sector $k$ in country $j$ can be written as:

$$
p_{j, t}^{k}=\mu_{j, t}^{k}+\tau w_{j, t}^{k}+(1-\tau) m_{j, t}^{k} .
$$

From the standard demand analysis, it is known that the optimal markup is inversely related to the underlying demand elasticity. In a perfectly competitive sector $k, \mu_{i, t}^{k}$ and $\mu_{j, t}^{k}$ equal zero. Under imperfect competition and effective segmentation between markets $i$ and $j$, monopolistically competitive firms can determine the optimal markups according to the demand elasticities in these markets. In addition, monopolistically competitive firms can stabilize local prices by adjusting the degree of exchange rate pass-through to prices. With such a pricing practice, markups can differ across markets $\left(\mu_{i, t} \neq \mu_{j, t}\right)$ and vary according to conditions in individual markets.

Let $e_{i, j, t}$ be the log of the nominal exchange rate defined as the number of $i$ 's currency units per $j$ 's currency and

$$
q_{i, j, t}^{k}=p_{i, t}^{k}-p_{j, t}^{k}-e_{i, j, t}
$$

be the cross-country sector $k$ relative price. Then, the effects of markup variation on cross-country relative price volatility can be inferred from the variance of the first difference of $q_{i, j, t}^{k}$ :

$$
\begin{aligned}
\operatorname{Var}\left(\Delta q_{i, j, t}^{k}\right)= & \operatorname{Var}\left(\Delta \mu_{i, t}^{k}-\Delta \mu_{j, t}^{k}\right)+\tau^{2} \operatorname{Var}\left(\Delta w_{i, t}^{k}-\Delta w_{j, t}^{k}\right)+\operatorname{Var}\left(\Delta e_{i, j, t}\right) \\
& +(1-\tau)^{2} \operatorname{Var}\left(\Delta m_{i, t}^{k}-\Delta m_{j, t}^{k}\right)-2 \operatorname{Cov}\left(\Delta \mu_{i, t}^{k}-\Delta \mu_{j, t}^{k}, \Delta e_{i, j, t}\right),
\end{aligned}
$$

where "Var" is the variance operator, " $\Delta$ " is the first-difference operator, "Cov" indicates covariance, and only the covariance between relative markups and exchange rates is assumed to be 
non-zero. Equation (4) shows that change in the relative markup, $\Delta \mu_{i, t}^{k}-\Delta \mu_{j, t}^{k}$, impacts the cross-country relative price volatility via a) its own variability, $\operatorname{Var}\left(\Delta \mu_{i, t}^{k}-\Delta \mu_{j, t}^{k}\right)$, and b) its comovement with exchange rate changes $\operatorname{Cov}\left(\Delta \mu_{i, t}^{k}-\Delta \mu_{j, t}^{k}, \Delta e_{i, j, t}\right)$. The variance term $\operatorname{Var}\left(\Delta \mu_{i, t}^{k}-\Delta \mu_{j, t}^{k}\right)$ depends on factors affecting relative markups and, for example, exchange rate pass-through is one of the possible factors. The covariance term $\operatorname{Cov}\left(\Delta \mu_{i, t}^{k}-\Delta \mu_{j, t}^{k}, \Delta e_{i, j, t}\right)$, on the other hand, measures the association between changes in the exchange rate and the relative markup and, thus, bears a more direct implication for the degree of exchange rate pass-through.

\section{Empirical Analysis of Market Structure Effects}

As illustrated in Section 3, cross-country relative price volatility is affected by pricing behavior in an imperfectly competitive market. Our empirical exercise focuses on the role of market structure factors because of the paucity of quality data on costs of non-traded and traded components for the sample under consideration. ${ }^{3}$

\section{4a. Price-Cost Margin}

We measure the markup using the price-cost margin (PCM) variable, which is commonly interpreted as a proxy for the degree of discriminatory pricing and monopolistic competition. The PCM for sector $k$ of country $i$ is defined as:

$$
P C M_{i, t}^{k}=\frac{V_{i, t}^{k}-M_{i, t}^{k}-W_{i, t}^{k}}{V_{i, t}^{k}}=\frac{V A_{i, t}^{k}-W_{i, t}^{k}}{V A_{i, t}^{k}+M_{i, t}^{k}}
$$

3. Cheung, Chinn and Fujii (2001), for example, offered some additional discussions of the role of market structure. 
where $V_{i, t}^{k}$ is the value of total production, $M_{i, t}^{k}$ is the cost of material inputs, $W_{i, t}^{k}$ is labor compensation, and $V A_{i, t}^{k}=\left(V_{i, t}^{k}-M_{i, t}^{k}\right)$ is the value added. Since the PCM can be derived from accounting data, it is widely used as a measure of market structure (Campa and Goldberg, 1995; Domowitz, Hubbard and Petersen, 1987). A larger value of the PCM represents a greater elevation of the price over the cost and a greater degree of monopolistic power.

Based on PCM, we construct three variables to capture market structure effects. The first variable is

$$
A P C M_{i, j}^{k}=\left(\overline{\ln P C M}_{i, t}^{k}+\overline{\ln P C M}_{j, t}^{k}\right) / 2,
$$

which is the average markup of sector $k$ in countries $i$ and $j$, in logarithms. The over-bar " “" denotes the sample mean over time $t$. While $A P C M_{i, j}^{k}$ is not included in (4), we speculate that sectors with a greater degree of monopolistic market power are likely to be more segmented and, hence, have a more variable cross-country relative price fluctuation. The relevance of this variable is assessed in the subsequent subsections.

The proxies for $\operatorname{Var}\left(\Delta \mu_{i, t}^{k}-\Delta \mu_{j, t}^{k}\right)$ and $\operatorname{Cov}\left(\Delta \mu_{i, t}^{k}-\Delta \mu_{j, t}^{k}, \Delta e_{i, j, t}\right)$ in (4) are:

$$
\operatorname{VPCM} M_{i, j}^{k}=\operatorname{Var}\left(\Delta\left(\ln P C M_{i, t}^{k}-\ln P C M_{j, t}^{k}\right)\right)
$$

and

$$
C P C M_{i, j}^{k}=-\operatorname{Cov}\left(\Delta\left(\ln P C M_{i, t}^{k}-\ln P C M_{j, t}^{k}\right), \Delta e_{i, j, t}\right) .
$$

Since $P C M_{i, t}^{k}$ and $P C M_{j, t}^{k}$ are proxies for the monopolistic markups $\mu_{i, t}^{k}$ and $\mu_{j, t}^{k}, V P C M_{i, j}^{k}$ can be interpreted as the empirical counterpart of $\operatorname{Var}\left(\Delta \mu_{i, t}^{k}-\Delta \mu_{j, t}^{k}\right)$ in equation (4). By the same token, the empirical counterpart of $\operatorname{Cov}\left(\Delta \mu_{i, t}^{k}-\Delta \mu_{j, t}^{k}, \Delta e_{i, j, t}\right)$ is given by $C P C M_{i, j}^{k}$. The 
pricing-to-market activity, for example, implies a negative covariance between relative PCM changes and exchange rate movements. To simplify the interpretation, we include a negative sign in defining $C P C M_{i, j}^{k}$ so that a more intensive pricing-to-market activity implies a larger value of $C P C M_{i, j}^{k}$. Indeed, $C P C M_{i, j}^{k}$ has a small but positive sample average suggesting that the interaction between relative PCM changes and exchange rate movements is likely to intensify cross-country relative price volatility. Further, $C P C M_{i, j}^{k}$ displays considerable variability as it has the largest coefficient of variation amongst the three market structure proxies. ${ }^{4}$

\section{4b. Effects on Cross-Country Relative Price Volatility}

Effects of market structure are investigated using the cross-sectional regression equation:

$$
\operatorname{Var}\left(\Delta q_{i, j}^{k}\right)=\beta D I S T_{i, j}+X^{\prime} \theta+\sum_{g=1}^{m} \alpha_{g} S D_{g}+\sum_{h=1}^{n} \gamma_{h} C D_{h}+u_{i, j}^{k}
$$

where $\operatorname{Var}\left(\Delta q_{i, j}^{k}\right)$ is the sample variance of $\Delta q_{i, j, t}^{k}$ (across time), DIST $T_{i, j}$ is the geographical distance in logarithms between countries $i$ and $j, X$ is a column vector containing explanatory variables that vary across specifications, $S D_{g}$ and $C D_{h}$ are the sector- and country-dummy variables, and $u_{i, j}^{k}$ is a disturbance term. The inclusion of the dummy variables allows the relative price volatility to assume different values among different countries and sectors.

The first specification considered is equation (9) without $X^{\prime} \theta$ and the estimation result is reported under the second column (labeled specification "1") in Table 1. The heteroskedasticityconsistent standard error (White, 1980) is reported underneath the coefficient estimate. In

4. The sample coefficients of variation of the three market structure variables are $0.14\left(A P C M_{i, j}^{k}\right), 1.99$ $\left(V P C M_{i, j}^{k}\right)$, and $28.26\left(C P C M_{i, j}^{k}\right)$. 
accordance with previous findings, the distance variable has a highly significant positive effect on cross-country relative price variability. The adjusted $\mathrm{R}^{2}$ is $56 \%$; indicating that the distance variable and the sector and country dummies explain slightly more than one half of the relative price variability.

Table 1. The Results of the Cross-Country Relative Price Volatility Regression

\begin{tabular}{|c|c|c|c|c|c|c|}
\hline & \multicolumn{6}{|c|}{ Model Specifications } \\
\hline & 1 & 2 & 3 & 4 & 5 & 6 \\
\hline Distance & $\begin{array}{r}0.0048^{* *} \\
(0.0004)\end{array}$ & $\begin{array}{l}-0.0006 \\
(0.0005)\end{array}$ & $\begin{array}{l}-0.0006 \\
(0.0005)\end{array}$ & $\begin{array}{l}-0.0007 \\
(0.0005)\end{array}$ & $\begin{array}{l}-0.0006 \\
(0.0005)\end{array}$ & $\begin{array}{l}-0.0007 \\
(0.0005)\end{array}$ \\
\hline $\begin{array}{l}\text { Exchange Rate } \\
\text { Volatility }\end{array}$ & & $\begin{array}{r}1.2622^{* *} \\
(0.0806)\end{array}$ & $\begin{array}{r}1.2769 * * \\
(0.0807)\end{array}$ & $\begin{array}{r}1.2575 * * \\
(0.0794)\end{array}$ & $\begin{array}{r}1.2460 * * \\
(0.0808)\end{array}$ & $\begin{array}{r}1.2565^{* *} \\
(0.0785)\end{array}$ \\
\hline$A P C M_{i, j}^{k}$ & & & $\begin{array}{r}0.0049 * * \\
(0.0018)\end{array}$ & & & $\begin{array}{r}0.0064^{* *} \\
(0.0019)\end{array}$ \\
\hline$V P C M_{i, j}^{k}$ & & & & $\begin{array}{r}0.0053^{* *} \\
(0.0017)\end{array}$ & & $\begin{array}{r}0.0083 * * \\
(0.0023)\end{array}$ \\
\hline$C P C M_{i, j}^{k}$ & & & & & $\begin{array}{r}0.1015^{* *} \\
(0.0354)\end{array}$ & $\begin{array}{r}0.1633 * * \\
(0.0402)\end{array}$ \\
\hline Adjusted $\mathrm{R}^{2}$ & 0.5594 & 0.6277 & 0.6281 & 0.6346 & 0.6326 & 0.6494 \\
\hline
\end{tabular}

Notes: The estimation results of equation (9) are presented. For all specifications, both country dummy and sector dummy variables are included, and the number of observations is 1344 . Heteroskedasticity-robust standard errors (White, 1980) are provided in parentheses. ${ }^{* *}$ and $*$ indicate statistical significance at, respectively, the $1 \%$ and $5 \%$ levels. See the text for definitions of the variables.

The third column (specification "2") of Table 1 reports the coefficient estimates of the second specification under which $X$ contains the sample variance of nominal exchange rate changes as an explanatory variable. The nominal exchange rate volatility is highly significant, and 
its coefficient is greater than unity. ${ }^{5}$ In the presence of exchange rate variability, the distance variable is statistically insignificant. ${ }^{6}$

The estimation results with $A P C M_{i, j}^{k}, V P C M_{i, j}^{k}$, and $C P C M_{i, j}^{k}$ sequentially included in $X$ are given under the headings of specifications 3 to 5. All the PCM variables are significantly positive. The significance of $A P C M_{i, j}^{k}$ indicates that sectors with a greater degree of monopolistic behavior tend to have a more variable cross-country relative price. One possible interpretation is that, in addition to adjusting prices, a high PCM offers sellers an extra degree of freedom to strategically respond to demand and supply conditions by varying the markups. The signs of $\operatorname{VPCM}_{i, j}^{k}$ and $C P C M_{i, j}^{k}$ are consistent with the predictions of (4). A variable relative PCM implies a volatile cross-country relative price, ceteris paribus. For $C P C M_{i, j}^{k}$, the evidence suggests that the relative PCM and the nominal exchange rate comove in a way to amplify the cross-country relative price variability. The positive coefficient is in accordance with the notion that firms reduce the markups to weaken the pass-through of exchange rate effect to local prices.

The results of specification 6, which includes all the three PCM variables simultaneously, indicate that the three market structure variables contain their own unique information on cross-country relative price variability. All the three PCM variables are jointly significant. In addition to the markup effects captured by $A P C M_{i, j}^{k}$ and $V P C M_{i, j}^{k}$, the $C P C M_{i, j}^{k}$ estimate attests to the relevance of pricing-to-market behavior, which affects the comovement between exchange rates and relative markups, for determining the cross-country relative price variability. It is noted

5. Similar results are found in Engel and Rogers (2001, Table 5). Equation (4), for instance, indicates that the nominal exchange rate can affect cross-country relative price volatility via two channels.

6. A similar replacement result is reported in some of the regressions in Engel and Rogers (2001). We do not have a persuasive explanation for the displacement result. However, it is noted that distance and nominal exchange rate variability have a sample correlation coefficient of 0.84 . The high sample correlation is not likely to be driven by the EMS countries. In fact, the two variables have a sample correlation coefficient of $0.46,0.90$, and 0.82 for the 
that the inclusion of these market structure variables does not materially affect the size or significance of the coefficient estimate on foreign exchange volatility.

Next, we investigate the robustness of the market structure effects to some control variables; namely Adjacency, Language, Sea, EEC, and EFTA. ${ }^{7}$ Adjacency is a dummy variable that assumes the value of one if the countries share a common border and zero otherwise. The dummy variable Language takes up the value of one if the countries share a common language. In some studies, this dummy variable is used as a proxy for informal trade barriers. If the two countries are separated by an ocean, then we set the Sea variable to one. EEC and EFTA are included to capture the effects of the two formal free trade agreements - the European Economic Community and the European Free Trade Agreement, respectively. ${ }^{8}$

The incremental effects of these explanatory variables are presented in Table 2 . While the Adjacency and Language variables have the expected negative sign and the Sea variable has the wrong sign, none of these three variables are significant when they are added to the equation individually or jointly. Similar insignificant results are also reported in Engel and Rogers (2001). ${ }^{9}$ The two trade agreement dummy variables have the expected negative sign. Nonetheless, only the negative coefficient estimate of EFTA is statistically significant, indicating that this trade agreement reduces relative price volatility among its member countries. It is noted that the inclusion of these control variables, separately or jointly, has a very limited implication for the PCM effects. Both the magnitude and significance of the three PCM variables are virtually unchanged across various specifications in Table 2. In sum, the PCM effects appear fairly robust.

EMS-EMS, EMS-nonEMS, and nonEMS-nonEMS country pairs, respectively.

7. These control dummy variables have been considered by, for example, Engel and Rogers (2001) and Parsley and Wei (1995).

8. Formally, the European Economic Community is more than a free-trade zone. It was first set up as a customs union with the intention of promoting additional economic integration among its member countries.

9. In Parsley and Wei (1995), which use the standard error instead of variance of relative prices as the regressand, Language is insignificant and Sea is highly significantly positive. The coefficient estimates of Adjacency and Language have different signs and levels of significance across subsamples in Engel and Rogers (2001). 
Table 2. The Results of the Cross-Country Relative Price Volatility Regression

\begin{tabular}{|c|c|c|c|c|c|c|}
\hline & \multicolumn{6}{|c|}{ Model Specifications } \\
\hline & 7 & 8 & 9 & 10 & 11 & 12 \\
\hline Distance & $\begin{array}{l}-0.0011 \\
(0.0006)\end{array}$ & $\begin{array}{l}-0.0008 \\
(0.0005)\end{array}$ & $\begin{array}{l}-0.0006 \\
(0.0005)\end{array}$ & $\begin{array}{l}-0.0010 \\
(0.0006)\end{array}$ & $\begin{array}{l}-0.0013 \\
(0.0006)\end{array}$ & $\begin{array}{l}-0.0013^{*} \\
(0.0006)\end{array}$ \\
\hline $\begin{array}{l}\text { Exchange Rate } \\
\text { Volatility }\end{array}$ & $\begin{array}{l}1.2554 * * \\
(0.0786)\end{array}$ & $\begin{array}{l}1.2203 * * \\
(0.0821)\end{array}$ & $\begin{array}{l}1.2816^{* *} \\
(0.0880)\end{array}$ & $\begin{array}{l}1.2639 * * \\
(0.0888)\end{array}$ & $\begin{array}{c}1.2755^{* *} \\
(0.0803)\end{array}$ & $\begin{array}{l}1.2560 * * \\
(0.0933)\end{array}$ \\
\hline$A P C M_{i, j}^{k}$ & $\begin{array}{c}0.0064 * * \\
(0.0019)\end{array}$ & $\begin{array}{c}0.0064^{* *} \\
(0.0019)\end{array}$ & $\begin{array}{c}0.0064^{* *} \\
(0.0019)\end{array}$ & $\begin{array}{c}0.0064 * * \\
(0.0019)\end{array}$ & $\begin{array}{c}0.0064^{* *} \\
(0.0019)\end{array}$ & $\begin{array}{l}0.0064^{* *} \\
(0.0019)\end{array}$ \\
\hline$V P C M_{i, j}^{k}$ & $\begin{array}{c}0.0083 * * \\
(0.0023)\end{array}$ & $\begin{array}{c}0.0083 * * \\
(0.0023)\end{array}$ & $\begin{array}{c}0.0083^{* *} \\
(0.0023)\end{array}$ & $\begin{array}{c}0.0083^{* *} \\
(0.0023)\end{array}$ & $\begin{array}{c}0.0083 * * \\
(0.0023)\end{array}$ & $\begin{array}{c}0.0083^{* *} \\
(0.0023)\end{array}$ \\
\hline$C P C M_{i, j}^{k}$ & $\begin{array}{c}0.1640 * * \\
(0.0402)\end{array}$ & $\begin{array}{c}0.1631^{* *} \\
(0.0403)\end{array}$ & $\begin{array}{c}0.1628 * * \\
(0.0402)\end{array}$ & $\begin{array}{c}0.1628^{* *} \\
(0.0403)\end{array}$ & $\begin{array}{c}0.1654^{* *} \\
(0.0400)\end{array}$ & $\begin{array}{c}0.1647^{* *} \\
(0.0401)\end{array}$ \\
\hline Adjacency & $\begin{array}{c}-0.0012 \\
(0.0009)\end{array}$ & & & $\begin{array}{l}-0.0008 \\
(0.0010)\end{array}$ & & $\begin{array}{l}-0.0000 \\
(0.0010)\end{array}$ \\
\hline Language & & $\begin{array}{l}-0.0014 \\
(0.0009)\end{array}$ & & $\begin{array}{l}-0.0014 \\
(0.0010\end{array}$ & & $\begin{array}{c}-0.0012 \\
(0.0010)\end{array}$ \\
\hline Sea & & & $\begin{array}{l}-0.0006 \\
(0.0012)\end{array}$ & $\begin{array}{l}-0.0011 \\
(0.0012)\end{array}$ & & $\begin{array}{l}-0.0003 \\
(0.0013)\end{array}$ \\
\hline EEC & & & & & $\begin{array}{l}-0.0015 \\
(0.0009)\end{array}$ & $\begin{array}{l}-0.0015 \\
(0.0010)\end{array}$ \\
\hline EFTA & & & & & $\begin{array}{c}-0.0046^{* *} \\
(0.0014)\end{array}$ & $\begin{array}{l}-0.0042 * \\
(0.0016)\end{array}$ \\
\hline Adjusted $\mathrm{R}^{2}$ & 0.6496 & 0.6496 & 0.6492 & 0.6495 & 0.6511 & 0.6506 \\
\hline
\end{tabular}

Notes: The estimation results of equation (9) are presented. For all specifications, both country dummy and sector dummy variables are included, and the number of observations is 1344 . Heteroskedasticity-robust standard errors (White, 1980) are provided in parentheses. ${ }^{* *}$ and $*$ indicate statistical significance at, respectively, the $1 \%$ and $5 \%$ levels. See the text for definitions of the variables.

\section{4c. Effects on Components}

In this subsection, we examine the market structure effects on the components of crosscountry relative price variation. For this purpose, we breakdown the cross-country relative price 
volatility into three components and consider the following decomposition:

$$
\operatorname{Var}\left(\Delta q_{i, j}^{k}\right) \equiv \operatorname{Var}\left(\Delta p_{i}^{k}-\Delta p_{j}^{k}\right)+\operatorname{Var}\left(\Delta e_{i, j}\right)-2 \operatorname{Cov}\left(\Delta e_{i, j}, \Delta p_{i}^{k}-\Delta p_{j}^{k}\right) .
$$

Equation (10) is an identity that gives the exact contributions of the three components to the total cross-country relative price variation. The relative contributions of the three components, by country and by sector, are presented in Appendix A. One notable observation is that the variances of inflation differentials and exchange rate changes account for the lion's share of cross-country relative price variability and the covariance term $\operatorname{Cov}\left(\Delta e_{i, j}, \Delta p_{i}^{k}-\Delta p_{j}^{k}\right)$ explains a very small proportion of the variability. On the average, the exchange rate change and the inflation differential each explains approximately $50 \%$ of the cross-country relative price variability.

Note that the decomposition formulation has variances (and covariance) of percentage changes on both sides of the identity. Since the variables are in logs, the two underlying components $p_{i, t}^{k}-p_{j, t}^{k}$ and $e_{i, j, t}$ have the same unit of measurement; that is i's currency per $j$ 's currency. One feature of (10) is that it isolates the nominal exchange rate effect from the price effect. Thus, we can assess the market structure effect on the corresponding price components of cross-country relative price variability. To this end, we estimate the two regression equations:

$$
\operatorname{Var}\left(\Delta p_{i}^{k}-\Delta p_{j}^{k}\right)=\beta D I S T_{i, j}+\theta X+\sum_{g=1}^{m} \alpha_{g} S D_{g}+\sum_{h=1}^{n} \gamma_{h} C D_{h}+u_{i, j}^{k}
$$

and

$$
\operatorname{Cov}\left(\Delta e_{i}, \Delta p_{i}^{k}-\Delta p_{j}^{k}\right)=\beta D I S T_{i, j}+\theta X+\sum_{g=1}^{m} \alpha_{g} S D_{g}+\sum_{h=1}^{n} \gamma_{h} C D_{h}+u_{i, j}^{k}
$$

The explanatory variables used in the previous subsection are also used in these regressions.

The estimation results for equation (11) are given in Table 3. A few observations are in order. First, the coefficient estimates of the distance and the nominal exchange rate variance variables are statistically insignificant; indicating that these two variables do not influence the 
inflation differential volatility $\operatorname{Var}\left(\Delta p_{i}^{k}-\Delta p_{j}^{k}\right)$. Second, the three PCM variables appear to be important factors determining the variance of inflation differentials. Both $A P C M_{i, j}^{k}$ and $V P C M_{i, j}^{k}$ display significant positive effects in all specifications under consideration. The results bear out the relevance of market structure on relative inflation variability. On the other hand, the effect of $C P C M_{i, j}^{k}$, which captures the comovement between changes in relative price-cost margins and exchange rates, is significantly positive only in the presence of the other two PCM variables. Third, none of the Adjacency, Language, Sea, or trade agreement dummy variables are found to affect the volatility of inflation differentials. ${ }^{10}$ These regression results suggest that the PCM variables have a significant influence on inflation differential volatility.

Table 3. The Results of the Inflation Differential Variability Regression

\begin{tabular}{|c|c|c|c|c|c|c|}
\hline & \multicolumn{6}{|c|}{ Model Specifications } \\
\hline & 1 & 2 & 3 & 4 & 5 & 6 \\
\hline Distance & $\begin{array}{c}0.0003 \\
(0.0003)\end{array}$ & $\begin{array}{l}-0.0000 \\
(0.0004)\end{array}$ & $\begin{array}{l}-0.0001 \\
(0.0004)\end{array}$ & $\begin{array}{l}-0.0000 \\
(0.0004)\end{array}$ & $\begin{array}{l}-0.0000 \\
(0.0004)\end{array}$ & $\begin{array}{l}-0.0001 \\
(0.0004)\end{array}$ \\
\hline $\begin{array}{l}\text { Exchange Rate } \\
\text { Volatility }\end{array}$ & & $\begin{array}{c}0.0791 \\
(0.0639)\end{array}$ & $\begin{array}{c}0.0927 \\
(0.0638)\end{array}$ & $\begin{array}{c}0.0751 \\
(0.0624)\end{array}$ & $\begin{array}{c}0.0716 \\
(0.0644)\end{array}$ & $\begin{array}{c}0.0812 \\
(0.0625)\end{array}$ \\
\hline$A P C M_{i, j}^{k}$ & & & $\begin{array}{r}0.0041^{* *} \\
(0.0117)\end{array}$ & & & $\begin{array}{r}0.0057 * * \\
(0.0015)\end{array}$ \\
\hline$V P C M_{i, j}^{k}$ & & & & $\begin{array}{r}0.0044 * * \\
(0.0016)\end{array}$ & & $\begin{array}{r}0.0062^{* *} \\
(0.0021)\end{array}$ \\
\hline$C P C M_{i, j}^{k}$ & & & & & $\begin{array}{l}0.0470 \\
(0.0303)\end{array}$ & $\begin{array}{c}0.0801^{*} \\
(0.0359)\end{array}$ \\
\hline Adjusted $\mathrm{R}^{2}$ & 0.6088 & 0.6089 & 0.6024 & 0.6170 & 0.6105 & 0.6185 \\
\hline
\end{tabular}

Notes: The estimation results of equation (11) are presented. For all specifications, both country dummy and sector dummy variables are included. The number of observations is 1344 .

10. These results are presented in Appendix A. 
Heteroskedasticity-robust standard errors (White, 1980) are provided in parentheses. ** and * indicate statistical significance at, respectively, the $1 \%$ and $5 \%$ levels. See the text for definitions of the variables.

Table 4. The Results of Exchange Rate Change - Inflation Differential Covariance Regression

\begin{tabular}{|c|c|c|c|c|c|c|}
\hline & \multicolumn{6}{|c|}{ Model Specifications } \\
\hline & 1 & 2 & 3 & 4 & 5 & 6 \\
\hline Distance & $\begin{array}{l}-0.0000 \\
(0.0001)\end{array}$ & $\begin{array}{l}0.0003^{*} \\
(0.0001)\end{array}$ & $\begin{array}{l}0.0002 * \\
(0.0001)\end{array}$ & $\begin{array}{l}0.0003^{*} \\
(0.0001)\end{array}$ & $\begin{array}{l}0.0003 * \\
(0.0001)\end{array}$ & $\begin{array}{l}0.0002 * \\
(0.0001)\end{array}$ \\
\hline $\begin{array}{l}\text { Exchange Rate } \\
\text { Volatility }\end{array}$ & & $\begin{array}{c}-0.0915^{* *} \\
(0.0227)\end{array}$ & $\begin{array}{c}-0.0920^{* *} \\
(0.0227)\end{array}$ & $\begin{array}{c}-0.0911^{* *} \\
(0.0227)\end{array}$ & $\begin{array}{c}-0.0872 * * \\
(0.0226)\end{array}$ & $\begin{array}{c}-0.0876^{* *} \\
(0.0225)\end{array}$ \\
\hline$A P C M_{i, j}^{k}$ & & & $\begin{array}{l}-0.0003 \\
(0.0004)\end{array}$ & & & $\begin{array}{c}-0.0003 \\
(0.0004)\end{array}$ \\
\hline$V P C M_{i, j}^{k}$ & & & & $\begin{array}{c}-0.0004 \\
(0.0002)\end{array}$ & & $\begin{array}{c}-0.1039 * * \\
(0.0003)\end{array}$ \\
\hline$C P C M_{i, j}^{k}$ & & & & & $\begin{array}{c}-0.0272 * * \\
(0.0073)\end{array}$ & $\begin{array}{c}-0.0416 * * \\
(0.0073)\end{array}$ \\
\hline Adjusted $\mathrm{R}^{2}$ & 0.1715 & 0.1826 & 0.1853 & 0.1835 & 0.1939 & 0.2086 \\
\hline
\end{tabular}

Notes: The estimation results of equation (12) are presented. For all specifications, both country dummy and sector dummy variables are included. The number of observations is 1344 . Heteroskedasticity-robust standard errors (White, 1980) are provided in parentheses. ** and * indicate statistical significance at, respectively, the $1 \%$ and $5 \%$ levels. See the text for definitions of the variables.

The estimation results for equation (12), which are given in Tables 4 and 5, can be summarized as follows. First, across all the specifications, distance and exchange rate volatility exhibit, respectively, a positive and a negative effect. Second, compared with inflation differential volatility, $\operatorname{Cov}\left(\Delta e_{i, j}, \Delta p_{i}^{k}-\Delta p_{j}^{k}\right)$ is affected by a smaller group of market structure variables. In these two tables $C P C M_{i, j}^{k}$ is the only PCM variable that displays a robust negative effect. The effect of $C P C M_{i, j}^{k}$ can be attributed to pricing to market. If $C P C M_{i, j}^{k}$ contains some information 
on exchange rate pass-through that influences local prices, then it helps explain the comovement of exchange rates and inflation differentials, which is represented by $\operatorname{Cov}\left(\Delta e_{i, j}, \Delta p_{i}^{k}-\Delta p_{j}^{k}\right)$. The variable $A P C M_{i, j}^{k}$ that measures the general level of non-competitiveness is insignificant across these specifications. Variability of the relative markup, $V P C M_{i, j}^{k}$, is significant with the expected sign only in the presence of $C P C M_{i, j}^{k}$.

Table 5. The Results of Exchange Rate Change-Inflation Differential Covariance Regression

\begin{tabular}{|c|c|c|c|c|c|c|}
\hline & \multicolumn{6}{|c|}{ Model Specifications } \\
\hline & 7 & 8 & 9 & 10 & 11 & 12 \\
\hline Distance & $\begin{array}{l}0.0003 * \\
(0.0001)\end{array}$ & $\begin{array}{l}0.0003^{*} \\
(0.0001)\end{array}$ & $\begin{array}{c}0.0002^{\#} \\
(0.0001)\end{array}$ & $\begin{array}{l}0.0003 * \\
(0.0001)\end{array}$ & $\begin{array}{l}0.0005^{* *} \\
(0.0001)\end{array}$ & $\begin{array}{l}0.0004 * * \\
(0.0001)\end{array}$ \\
\hline $\begin{array}{l}\text { Exchange Rate } \\
\text { Volatility }\end{array}$ & $\begin{array}{c}-0.0874^{* *} \\
(0.0225)\end{array}$ & $\begin{array}{c}-0.0702^{* *} \\
(0.0230)\end{array}$ & $\begin{array}{c}-0.1026^{* *} \\
(0.0259)\end{array}$ & $\begin{array}{c}-0.0941^{* *} \\
(0.0256)\end{array}$ & $\begin{array}{c}-0.0944 * * \\
(0.0227)\end{array}$ & $\begin{array}{c}-0.0927 * * \\
(0.0264)\end{array}$ \\
\hline$A P C M_{i, j}^{k}$ & $\begin{array}{l}-0.0003 \\
(0.0004)\end{array}$ & $\begin{array}{l}-0.0003 \\
(0.0004)\end{array}$ & $\begin{array}{l}-0.0003 \\
(0.0004)\end{array}$ & $\begin{array}{l}-0.0003 \\
(0.0004)\end{array}$ & $\begin{array}{l}-0.0003 \\
(0.0004)\end{array}$ & $\begin{array}{l}-0.0003 \\
(0.0004)\end{array}$ \\
\hline$V P C M_{i, j}^{k}$ & $\begin{array}{c}-0.0010 * * \\
(0.0003)\end{array}$ & $\begin{array}{c}-0.0010^{* *} \\
(0.0003)\end{array}$ & $\begin{array}{c}-0.0010^{* *} \\
(0.0003)\end{array}$ & $\begin{array}{c}-0.0010^{* *} \\
(0.0003)\end{array}$ & $\begin{array}{c}-0.0010 * * \\
(0.0003)\end{array}$ & $\begin{array}{c}-0.0010 * * \\
(0.0003)\end{array}$ \\
\hline$C P C M_{i, j}^{k}$ & $\begin{array}{c}-0.0417 * * \\
(0.0073)\end{array}$ & $\begin{array}{c}-0.0415^{* *} \\
(0.0073)\end{array}$ & $\begin{array}{c}-0.0413 * * \\
(0.0073)\end{array}$ & $\begin{array}{c}-0.0410 * * \\
(0.0073)\end{array}$ & $\begin{array}{c}-0.0423 * * \\
(0.0072)\end{array}$ & $\begin{array}{c}-0.0417 * * \\
(0.0072)\end{array}$ \\
\hline Adjacency & $\begin{array}{c}0.0002 \\
(0.0002)\end{array}$ & & & $\begin{array}{c}0.0000 \\
(0.0002)\end{array}$ & & $\begin{array}{l}-0.0002 \\
(0.0002)\end{array}$ \\
\hline Language & & $\begin{array}{l}0.0006^{* *} \\
(0.0002)\end{array}$ & & $\begin{array}{c}0.0008^{* *} \\
(0.0002)\end{array}$ & & $\begin{array}{l}0.0008^{* *} \\
(0.0002)\end{array}$ \\
\hline Sea & & & $\begin{array}{c}0.0003 \\
(0.0003)\end{array}$ & $\begin{array}{l}0.0007^{*} \\
(0.0003)\end{array}$ & & $\begin{array}{c}0.0005 \\
(0.0003)\end{array}$ \\
\hline EEC & & & & & $\begin{array}{l}0.0005^{*} \\
(0.0002)\end{array}$ & $\begin{array}{c}0.0004^{\#} \\
(0.0002)\end{array}$ \\
\hline EFTA & & & & & $\begin{array}{l}0.0016 * * \\
(0.0003)\end{array}$ & $\begin{array}{c}0.0015^{* *} \\
(0.0004)\end{array}$ \\
\hline Adjusted $\mathrm{R}^{2}$ & 0.2088 & 0.2114 & 0.2087 & 0.2126 & 0.2159 & 0.2387 \\
\hline
\end{tabular}


Notes: The estimation results of equation (12) are presented. For all specifications, both country dummy and sector dummy variables are included. The number of observations is 1344 . Heteroskedasticity-robust standard errors (White, 1980) are provided in parentheses. **, *, and * indicate statistical significance at, respectively, the $1 \%, 5 \%$, and $10 \%$ levels. See the text for definitions of the variables.

Third, the Language and two trade agreement (EEC and EFTA) variables are significant and have the expected sign. However, their presence does not alter the significance of the PCM variables. The significance of two trade agreement variables is supportive of the view that free trade agreements make prices more responsive to exchange rate fluctuations.

Undoubtedly, the regression results lend considerable support for the market structure effect and are quite intuitive. For instance, the variables $A P C M_{i, j}^{k}$ and $V P C M_{i, j}^{k}$ are proxies derived from PCM, which is a measure of the degree of market imperfection. These variables, thus, are likely to have direct impacts on relative local price behavior. Indeed, the two variables are found to have more profound effects on the variance of inflation differentials than on the covariance of exchange rate variations and inflation differentials. In general, these findings reinforce the effects of market structure reported in the previous subsection.

\section{4d. Some Robustness Analyses}

To investigate the robustness of the empirical market structure effects, we conduct a few alternative analyses. First, the global economy is increasingly integrated over time. During the sample period, the barriers to international trade and capital flows are weakening. It is worthwhile investigating whether cross-country relative price volatility and market structure effects have changed over time. Constrained by the sample size, we repeated the preceding empirical exercise on only two subsamples: 1970-1982 and 1983-1994. The results were collected in Appendix B. 
Second, we examine the market structure effect using a different industry classification scheme and the results were reported in Appendix C.

The subsample analysis (reported in Appendix B) can be summarized as follows. First, all the sectoral averages of cross-country relative price volatility from the second subsample are smaller than those from the first one. For country averages, only Australia exhibits an increase. The general decline in cross- country relative price volatility is consistent with the notion of increasing global integration.

Second, there are some discernible changes in the composition of cross-country relative price volatility. While the cross-country relative price volatility decreases, the relative contribution of nominal exchange rate variability is more significant and increases uniformly for both the sector and country categories in the second subsample. On the average, the contribution of the nominal exchange rate effect surges from $40 \%$ to $62 \%$. The covariance term, in general, is small and tends to change its sign across the two subsample periods. As a result of the sign change, the covariance term adds to cross-country relative price volatility in the first subsample but reduces it in the second one. The evidence indicates that local prices respond slightly better to exchange rate fluctuations in the second susbsample.

Third, the overall market structure effect is slightly more prominent in the first subsample than in the second one. For instance, $\operatorname{Cov}\left(\Delta e_{i, j}, \Delta p_{i}^{k}-\Delta p_{j}^{k}\right)$ is only affected by $C P C M_{i, j}^{k}$ in the second subsample. One possible interpretation is that, with reduction in barriers to trade and capital flows, local prices become more responsive to exchange rates. Such a change will weaken the effect of $A P C M_{i, j}^{k}$ and $\operatorname{VPCM} M_{i, j}^{k}$ on $\operatorname{Cov}\left(\Delta e_{i, j}, \Delta p_{i}^{k}-\Delta p_{j}^{k}\right)$ and hence, $\operatorname{Var}\left(\Delta q_{i, j}^{k}\right)$ in the latter sample period. Importantly, the estimates of these market structure variables are quite insensitive 
to the presence of control variables.

As indicated in footnote 2, the new industry classification system - ISIC Revision 3, recently implemented by OECD offers a limited country sample but a few additional years of data for our analysis. Specifically, under the new classification scheme and for the 1970-1998 period, only nine countries in our sample that have complete observations on value of total production, value added in the current price, value added in the constant price, and labor compensation, which are required to calculate PCM and sectoral price indexes. ${ }^{11}$ In addition, we had to drop some sectors under the ISIC Revision 3 convention because of missing observations. Consequently, the effective sample size of our cross-country-cum-cross-sector regression analysis is severely reduced.

To check for robustness of our results, we nevertheless replicated our empirical exercise using data available under the ISIC Revision 3 codes. To facilitate comparison, we also re-did the exercise using the ISIC Revision 2 data for the countries and sectors that are included in the ISIC Revision 3 sample. These additional estimation results were given in Appendix C. In general, the results of these exercises corroborate the finding of empirical market structure effects reported in the previous subsections. The estimation results derived from the ISIC Revision 3 data and those from the corresponding ISIC Revision 2 data are qualitatively the same. Furthermore, the results based on the two nine-country samples (ISIC Revision 2 and Revision 3) are quite similar to those obtained from the original 18-country sample. Specifically, increases in monopolistic market power and nominal exchange rate volatility are associated with greater variability of cross-country relative prices. Thus, the reported market structure effect on cross-country relative price variability

11. The countries are Belgium, Canada, Denmark, Finland, Italy, Japan, Netherlands, Norway, and the U.K. The sample period can be extended from 1998 to 2000. In this case, however, the effective country sample size is further reduced as four of the nine countries have adopted the common currency euro since 1999. 
is quite robust.

\section{Summary}

One intriguing price behavior is the resilient variability exhibited by the exchanged-rateadjusted relative prices of similar goods across countries. The existing empirical literature suggests that a large portion of cross-country relative price variability is not explained by factors including nominal exchange rate variability and distance. Motivated by a standard markup pricing formulation, we examine the role of market structure as a determinant of cross-country relative price variability.

Using data on nine manufacturing sectors across eighteen OECD countries, we reveal considerable evidence of market structure effects on both cross-country relative price volatility itself and its components. The reported market structure effects are robust to some common control variables considered in the literature. Results from subsample analyses and alternative sample specifications also affirm the presence of market structure effects.

It is noted that there is a non-negligible portion of cross-country relative price variability unaccounted for by the factors considered in the current exercise. The discussion in section 3 , for example, indicates that the costs of traded and non-traded inputs should be considered. It is also conceived that differences in distribution systems and inventory management methods may affect cross-country relative price variability. ${ }^{12}$ Unfortunately, we do not have data on these variables. Future research on the other potential determinants of relative price variability across countries is warranted.

12. MacDonald and Ricci (2001) examine the impact of the distribution sector on real exchange rate dynamics and convergence. 


\section{References:}

Campa, Jose M. and Linda S. Goldberg. "Investment in manufacturing, exchange rates and external exposure.” Journal of International Economics, 1995, 38: 297-320.

Cheung, Yin-Wong, Menzie Chinn and Eiji Fujii. “Market structure and the persistence of sectoral real exchange rates.” International Journal of Finance \& Economics, 2001, 6: 95-114.

Domowitz, Ian, R. Glenn Hubbard and Bruce C. Petersen, "Oligopoly supergames: Some empirical evidence on prices and margins." Journal of Industrial Economics, 1987, 35: 379-398.

Engel, Charles. 1993. "Real exchange rates and relative prices: An empirical investigation." Journal of Monetary Economics, August 1993, 32 (1): 35-50.

Engel, Charles. 1999. “Accounting for the U.S real exchange rate changes.” Journal of Political Economy, June 1999, 107(3): 507-538.

Engel, Charles and John H. Rogers. “How wide is the border?” American Economic Review, December 1996, 86(5): 1112-1125.

Engel, Charles and John H. Rogers. “Relative price volatility: What role does the border play?” in Gregory D. Hess and Eric van Wincoop, eds., Intranational Macroeconomics, Cambridge University Press, 2000: 92-111.

Engel, Charles and John H. Rogers. "Deviations from purchasing power parity: Causes and welfare costs.” Journal of International Economics, 2001, 55: 29-57.

Goldberg, Pinelopi Koujianou and Frank Verboven. "Market integration and convergence to the law of one price: evidence from the European car market.” National Bureau of Economic Research Working Paper 8402, July 2001.

Haskel, Jonathan and Holger Wolf. "The law of one price - A case study.” CESifo Working Paper 428, 2001.

Isard, Peter. "How far can we push the 'Law of one price'?” American Economic Review, 
December 1977, 67(5): 942-48.

MacDonald, Ronald and Luca Ricci. "PPP and the Balassa Samuelson effect: The role of the distribution sector.” CESifo Working Paper, 2001.

Parsley, David C. and Shiang-Jin Wei. "Purchasing power disparity during the floating rate period: Exchange rate volatility, trade barriers and other culprits.” National Bureau of Economic Research Working Paper 5032, February 1995.

Parsley, David C. and Shang-Jin Wei. "Explaining the border effect: The role of exchange rate variability, shipping cost, and geography.” Journal of International Economics, 2001, 55: 87-105.

White, Halbert. "A heteroskedasticity-consistent covariance matrix and a direct test for heteroskedasticity.” Econometrica, May 1980, 48 (4): 817-838. 
Appendix A

Decomposition of cross-country relative price volatility and additional results of the inflation differential variability regression 


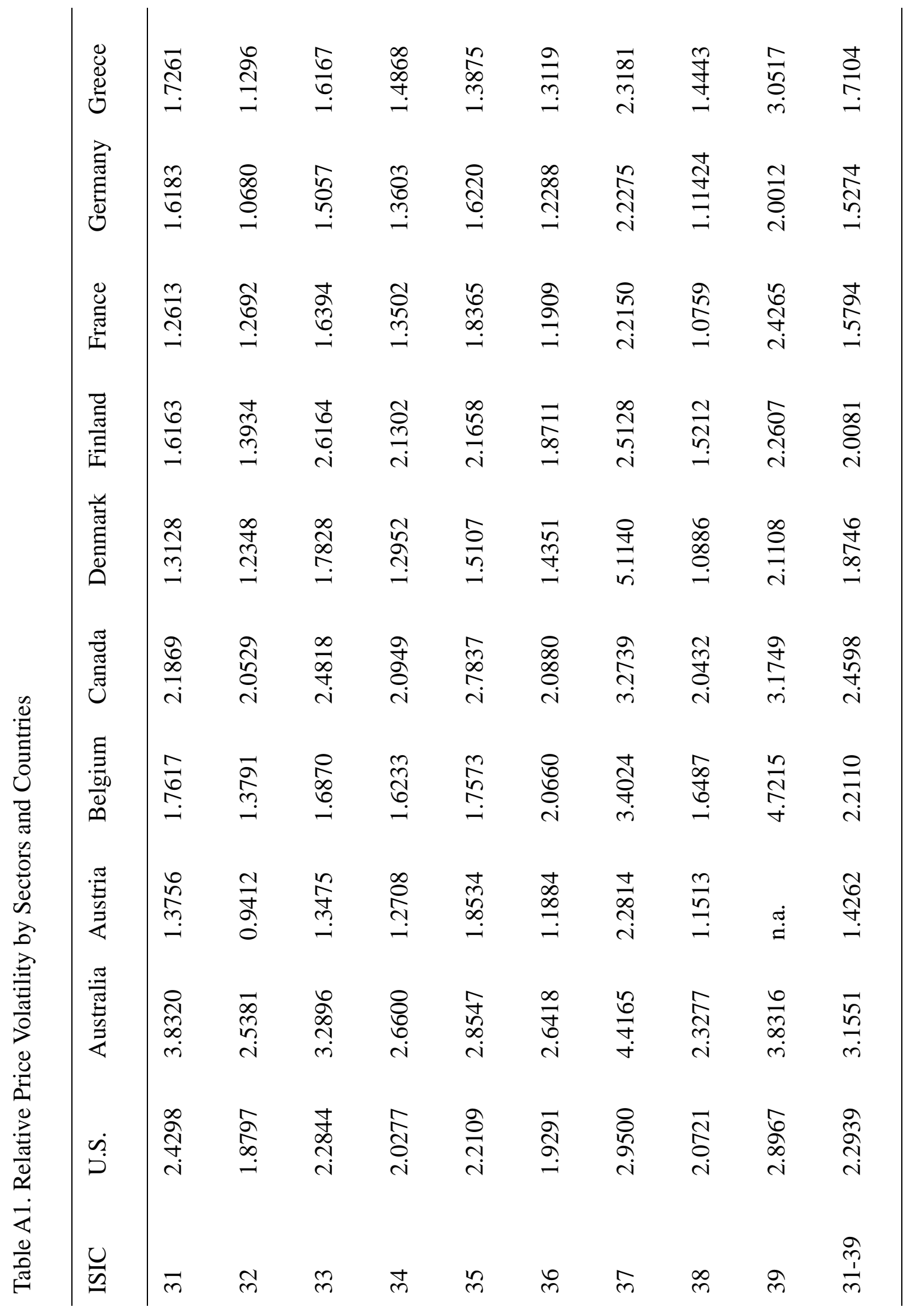




\begin{tabular}{|c|c|c|c|c|c|c|c|c|c|c|}
\hline $\bar{Z}$ & 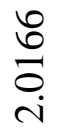 & 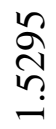 & 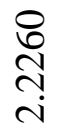 & 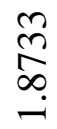 & 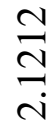 & 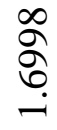 & $\begin{array}{l}\text { Dे } \\
\text { ᄋे } \\
\text { m. }\end{array}$ & 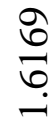 & $\begin{array}{l}\vec{b} \\
\infty \\
\stackrel{1}{1} \\
\dot{m}\end{array}$ & 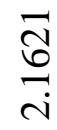 \\
\hline بط & $\begin{array}{l}\widehat{N} \\
\text { ํㅜ } \\
\text { i. }\end{array}$ & 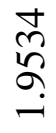 & 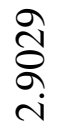 & $\begin{array}{l}\infty \\
\text { N్} \\
\text { } \\
\text { N }\end{array}$ & 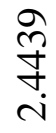 & 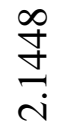 & $\begin{array}{l}\text { bै } \\
\text { N } \\
\text { }\end{array}$ & 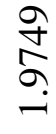 & 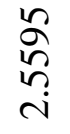 & 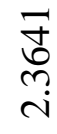 \\
\hline $\begin{array}{l}\overline{0} \\
\frac{0}{d} \\
3 \\
\omega\end{array}$ & $\begin{array}{l}\infty \\
\stackrel{n}{m} \\
\stackrel{-1}{-}\end{array}$ & $\begin{array}{l}\stackrel{v}{\sim} \\
\stackrel{n}{n}\end{array}$ & 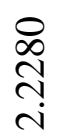 & 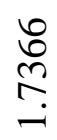 & 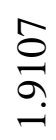 & 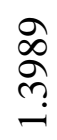 & 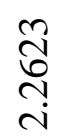 & 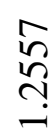 & $\begin{array}{l}\infty \\
\infty \\
\stackrel{0}{-} \\
\dot{m}\end{array}$ & 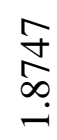 \\
\hline 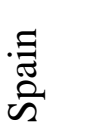 & 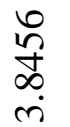 & 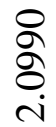 & $\begin{array}{l}\stackrel{\sim}{\sim} \\
\text { ָे } \\
\text { ஸे }\end{array}$ & 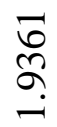 & 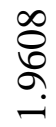 & 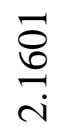 & 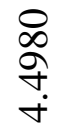 & $\begin{array}{l}m \\
\substack{+\infty \\
\sim} \\
\sim\end{array}$ & 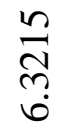 & $\begin{array}{l}\stackrel{0}{\hat{m}} \\
\stackrel{m}{m}\end{array}$ \\
\hline 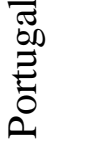 & 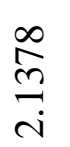 & 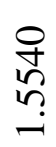 & 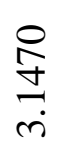 & 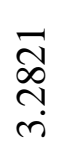 & $\begin{array}{l}m \\
\stackrel{n}{\mathscr{g}} \\
\text { d. }\end{array}$ & 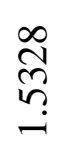 & $\frac{n}{m}$ & $\begin{array}{l}\text { Nิ } \\
\stackrel{0}{0} \\
\text { N }\end{array}$ & $\begin{array}{l}\stackrel{\infty}{N} \\
\underset{\sim}{\not} \\
\underset{+}{+}\end{array}$ & 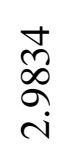 \\
\hline $\begin{array}{l}\vec{\pi} \\
3 \\
0 \\
z\end{array}$ & $\begin{array}{l}\infty \\
\infty \\
\infty \\
\infty \\
-1\end{array}$ & $\begin{array}{l}0 \\
\hat{0} \\
0 \\
0 \\
0\end{array}$ & 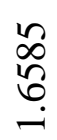 & $\underset{\sim}{\stackrel{\text { f }}{f}}$ & $\begin{array}{l}\text { ని } \\
\stackrel{\infty}{\infty} \\
-\end{array}$ & 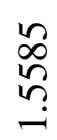 & 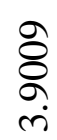 & 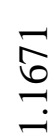 & $\begin{array}{l}\infty \\
\infty \\
\stackrel{N}{N} \\
\text { N } \\
\sim\end{array}$ & 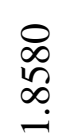 \\
\hline 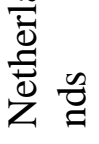 & 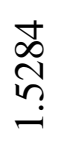 & $\begin{array}{l}\text { స్ } \\
\text { ઼ָ } \\
-1\end{array}$ & 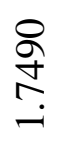 & 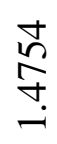 & 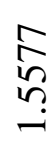 & 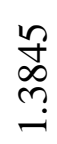 & $\begin{array}{l}m \\
m \\
\tilde{m} \\
\tilde{n}\end{array}$ & 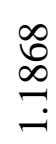 & 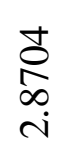 & 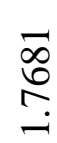 \\
\hline 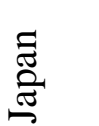 & 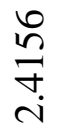 & 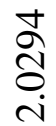 & $\frac{\stackrel{L}{\stackrel{2}{+}}}{\stackrel{\sim}{\sim}}$ & 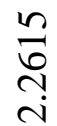 & $\begin{array}{l}\hat{\sigma} \\
\text { 감 }\end{array}$ & 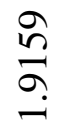 & 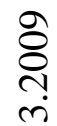 & 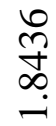 & $\begin{array}{l}\text { 吕 } \\
\text { مू } \\
\text { N }\end{array}$ & 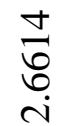 \\
\hline$\stackrel{\nexists}{\Xi}$ & 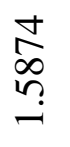 & 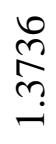 & 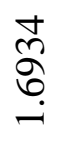 & $\begin{array}{l}\text { 으 } \\
\text { மூ } \\
\text { مุ }\end{array}$ & 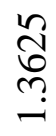 & 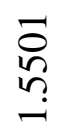 & $\begin{array}{l}\hat{\sigma} \\
\text { D } \\
\text { ㅁ. }\end{array}$ & 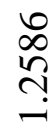 & $\begin{array}{l}\underset{+}{+} \\
\stackrel{+}{+} \\
\dot{\theta}\end{array}$ & $\begin{array}{l}0 \\
\infty \\
\infty \\
\infty \\
-1\end{array}$ \\
\hline$\underset{\sim}{\varrho}$ & $\bar{m}$ & ๓े & $m$ & ले & ำ & బొ & $\hat{n}$ & ద్లి & ని & $\begin{array}{l}\text { m } \\
\frac{1}{m}\end{array}$ \\
\hline
\end{tabular}

Notes: The entries are sample variances of sectoral relative prices of the specified sectors and countries. Sectors are denoted by their international standard industry classification (ISIC) codes in the first column. 
Table A2 Decomposition of Cross-Country Relative Price Volatility
A. By Sector

\begin{tabular}{|c|c|c|c|c|}
\hline & $\operatorname{Var}\left(\Delta q_{i, j}^{k}\right)$ & $\frac{\operatorname{Var}\left(\Delta e_{i, j}\right)}{\operatorname{Var}\left(\Delta q_{i, j}^{k}\right)}$ & $\frac{\operatorname{Var}\left(\Delta p_{i}^{k}-\Delta p_{j}^{k}\right)}{\operatorname{Var}\left(\Delta q_{i, j}^{k}\right)}$ & $\frac{-2 \operatorname{Cov}\left(\Delta e_{i, j}, \Delta p_{i}^{k}-\Delta p_{j}^{k}\right)}{\operatorname{Var}\left(\Delta q_{i, j}^{k}\right)}$ \\
\hline $\begin{array}{l}\text { 31: Food, beverages and } \\
\text { tobacco }\end{array}$ & 2.0166 & 0.5312 & 0.4318 & 0.0370 \\
\hline $\begin{array}{l}\text { 32: Textiles, apparel and } \\
\text { leather }\end{array}$ & 1.5295 & 0.7004 & 0.3563 & -.0566 \\
\hline $\begin{array}{l}\text { 33: Wood products and } \\
\text { furniture }\end{array}$ & 2.2260 & 0.4813 & 0.4658 & 0.0530 \\
\hline $\begin{array}{l}\text { 34: Paper, paper products } \\
\text { and printing }\end{array}$ & 1.8733 & 0.5719 & 0.4604 & -.0323 \\
\hline 35: Chemical products & 2.1212 & 0.5050 & 0.4447 & 0.0503 \\
\hline $\begin{array}{l}\text { 36: Non-metallic mineral } \\
\text { products }\end{array}$ & 1.6998 & 0.6302 & 0.4088 & -.0391 \\
\hline $\begin{array}{l}\text { 37: Basic metal } \\
\text { industries }\end{array}$ & 3.3036 & 0.3243 & 0.7373 & -.0616 \\
\hline $\begin{array}{l}\text { 38: Fabricated metal } \\
\text { products }\end{array}$ & 1.6169 & 0.6626 & 0.3264 & 0.0111 \\
\hline 39: Other manufacturing & 3.1861 & 0.3362 & 0.6348 & 0.0157 \\
\hline 31-39: & 2.1621 & 0.4955 & 0.5055 & -.0026 \\
\hline
\end{tabular}


B. By Country

\begin{tabular}{lcccc}
\hline & $\operatorname{Var}\left(\Delta q_{i, j}^{k}\right)$ & $\frac{\operatorname{Var}\left(\Delta e_{i, j}\right)}{\operatorname{Var}\left(\Delta q_{i, j}^{k}\right)}$ & $\frac{\operatorname{Var}\left(\Delta p_{i}^{k}-\Delta p_{j}^{k}\right)}{\operatorname{Var}\left(\Delta q_{i, j}^{k}\right)}$ & $\frac{-2 \operatorname{Cov}\left(\Delta e_{i, j}, \Delta p_{i}^{k}-\Delta p_{j}^{k}\right)}{\operatorname{Var}\left(\Delta q_{i, j}^{k}\right)}$ \\
\hline U.S. & 2.2939 & 0.6485 & 0.3291 & 0.0222 \\
Australia & 3.1551 & 0.6143 & 0.3765 & 0.0101 \\
Austria & 1.4262 & 0.5489 & 0.4997 & -.0432 \\
Belgium & 2.2110 & 0.3688 & 0.5653 & 0.0636 \\
Canada & 2.4598 & 0.6217 & 0.3650 & 0.0134 \\
Denmark & 1.8746 & 0.3974 & 0.5612 & 0.0390 \\
Finland & 2.0081 & 0.4245 & 0.5484 & 0.0260 \\
France & 1.5794 & 0.5042 & 0.4760 & 0.0176 \\
Germany & 1.5274 & 0.5342 & 0.4634 & -.0010 \\
Greece & 1.7104 & 0.5278 & 0.6465 & -.1749 \\
Italy & 1.8876 & 0.5406 & 0.5582 & -.0992 \\
Japan & 2.6614 & 0.6199 & 0.3913 & -.0115 \\
Netherlands & 1.7681 & 0.4348 & 0.5540 & 0.0084 \\
Norway & 1.8580 & 0.3875 & 0.6031 & 0.0082 \\
Portugal & 2.9834 & 0.4158 & 0.6701 & -.0857 \\
Spain & 3.1976 & 0.3248 & 0.6354 & 0.0391 \\
Sweden & 1.8747 & 0.4907 & 0.4826 & 0.0256 \\
U.K. & 2.3641 & 0.5325 & 0.4142 & 0.0525 \\
All & 2.1621 & 0.4955 & 0.5055 & -.0026 \\
\hline
\end{tabular}

Notes: $\operatorname{Var}\left(\Delta q_{i, j}^{k}\right)$ gives the sample variances of cross-country relative prices. The proportions of $\operatorname{Var}\left(\Delta q_{i, j}^{k}\right)$ explained by variance of exchange rate changes, variance of inflation differentials, and covariance of exchange rate changes and inflation differentials are given by $\operatorname{Var}\left(\Delta e_{i, j}\right) / \operatorname{Var}\left(\Delta q_{i, j}^{k}\right), \operatorname{Var}\left(\Delta p_{i}^{k}-\Delta p_{j}^{k}\right) / \operatorname{Var}\left(\Delta q_{i, j}^{k}\right)$, and $-2 \operatorname{Cov}\left(\Delta e_{i, j}, \Delta p_{i}^{k}-\Delta p_{j}^{k}\right) / \operatorname{Var}\left(\Delta q_{i, j}^{k}\right)$. 
Table A3. Additional Results of the Inflation Differential Variability Regression

\begin{tabular}{|c|c|c|c|c|c|c|}
\hline & \multicolumn{6}{|c|}{ Model Specifications } \\
\hline & 7 & 8 & 9 & 10 & 11 & 12 \\
\hline Distance & $\begin{array}{l}-0.0003 \\
(0.0005)\end{array}$ & $\begin{array}{l}-0.0001 \\
(0.0004)\end{array}$ & $\begin{array}{l}-0.0001 \\
(0.0004)\end{array}$ & $\begin{array}{l}-0.0003 \\
(0.0005)\end{array}$ & $\begin{array}{l}-0.0003 \\
(0.0005)\end{array}$ & $\begin{array}{l}-0.0005 \\
(0.0005)\end{array}$ \\
\hline $\begin{array}{l}\text { Exchange Rate } \\
\text { Volatility }\end{array}$ & $\begin{array}{c}0.0806 \\
(0.0624)\end{array}$ & $\begin{array}{c}0.0798 \\
(0.0658)\end{array}$ & $\begin{array}{c}0.0763 \\
(0.0697)\end{array}$ & $\begin{array}{c}0.0755 \\
(0.0706)\end{array}$ & $\begin{array}{c}0.0867 \\
(0.0640)\end{array}$ & $\begin{array}{c}0.0705 \\
(0.0741)\end{array}$ \\
\hline$A P C M_{i, j}^{k}$ & $\begin{array}{c}0.0057 * * \\
(0.0015)\end{array}$ & $\begin{array}{c}0.0057 * * \\
(0.0015)\end{array}$ & $\begin{array}{c}0.0057 * * \\
(0.0015)\end{array}$ & $\begin{array}{c}0.0057^{* *} \\
(0.0015)\end{array}$ & $\begin{array}{c}0.0057^{* *} \\
(0.0015)\end{array}$ & $\begin{array}{c}0.0057 * * \\
(0.0015)\end{array}$ \\
\hline$V P C M_{i, j}^{k}$ & $\begin{array}{c}0.0062 * * \\
(0.0021)\end{array}$ & $\begin{array}{c}0.0062 * * \\
(0.0021)\end{array}$ & $\begin{array}{c}0.0062 * * \\
(0.0021)\end{array}$ & $\begin{array}{c}0.0062 * * \\
(0.0021)\end{array}$ & $\begin{array}{l}0.0062 * * \\
(0.0021)\end{array}$ & $\begin{array}{c}0.0062 * * \\
(0.0021)\end{array}$ \\
\hline$C P C M_{i, j}^{k}$ & $\begin{array}{l}0.0805^{*} \\
(0.0360)\end{array}$ & $\begin{array}{l}0.0801^{*} \\
(0.0359)\end{array}$ & $\begin{array}{l}0.0802 * \\
(0.0359)\end{array}$ & $\begin{array}{l}0.0808 * \\
(0.0360)\end{array}$ & $\begin{array}{l}0.0807 * \\
(0.0360)\end{array}$ & $\begin{array}{l}0.0812 * \\
(0.0360)\end{array}$ \\
\hline Adjacency & $\begin{array}{l}-0.0007 \\
(0.0007)\end{array}$ & & & $\begin{array}{l}-0.0008 \\
(0.0008)\end{array}$ & & $\begin{array}{l}-0.0005 \\
(0.0008)\end{array}$ \\
\hline Language & & $\begin{array}{l}-0.0000 \\
(0.0007)\end{array}$ & & $\begin{array}{c}0.0003 \\
(0.0008)\end{array}$ & & $\begin{array}{c}0.0003 \\
(0.0008)\end{array}$ \\
\hline Sea & & & $\begin{array}{c}0.0001 \\
(0.0009)\end{array}$ & $\begin{array}{c}0.0003 \\
(0.0009)\end{array}$ & & $\begin{array}{c}0.0006 \\
(0.0010)\end{array}$ \\
\hline EEC & & & & & $\begin{array}{l}-0.0005 \\
(0.0007)\end{array}$ & $\begin{array}{l}-0.0005 \\
(0.0008)\end{array}$ \\
\hline EFTA & & & & & $\begin{array}{l}-0.0013 \\
(0.0011)\end{array}$ & $\begin{array}{l}-0.0011 \\
(0.0013)\end{array}$ \\
\hline Adjusted $\mathrm{R}^{2}$ & 0.6184 & 0.6182 & 0.6182 & 0.6179 & 0.6182 & 0.6276 \\
\hline
\end{tabular}

Notes: The estimation results of equation (11) are presented. For all specifications, both country dummy and sector dummy variables are included. The number of observations is 1344 . Heteroskedasticity-robust standard errors (White, 1980) are provided in parentheses. ** and * indicate statistical significance at, respectively, the $1 \%$ and $5 \%$ levels. See the text for definitions of the variables. 
Appendix B

Results of sub-sample analyses

B1: 1971-1982

B2: 1983-1994 
Table B1-1. The Results of the Cross-Country Relative Price Volatility Regression for 1971-1982

\begin{tabular}{|c|c|c|c|c|c|c|}
\hline & \multicolumn{6}{|c|}{ Model Specifications } \\
\hline & 1 & 2 & 3 & 4 & 5 & 6 \\
\hline Distance & $\begin{array}{l}0.0039 * * \\
(0.0007)\end{array}$ & $\begin{array}{l}-0.0004 \\
(0.0008)\end{array}$ & $\begin{array}{l}-0.0004 \\
(0.0008)\end{array}$ & $\begin{array}{l}-0.0005 \\
(0.0008)\end{array}$ & $\begin{array}{l}-0.0004 \\
(0.0008)\end{array}$ & $\begin{array}{l}-0.0004 \\
(0.0008)\end{array}$ \\
\hline Exchange & & $1.2533 * *$ & $1.2479 * *$ & $1.2497 * *$ & $1.2426 * *$ & $1.2328 * *$ \\
\hline Rate & & $(0.1312)$ & $(0.1306)$ & $(0.1317)$ & $(0.1308)$ & $(0.1308)$ \\
\hline Volatility & & & & & & \\
\hline$A P C M_{i, j}^{k}$ & & & $\begin{array}{l}0.0055^{* *} \\
(0.0020)\end{array}$ & & & $\begin{array}{l}0.0073 * * \\
(0.0023)\end{array}$ \\
\hline$V P C M_{i, j}^{k}$ & & & & $\begin{array}{l}0.0036^{*} \\
(0.0015)\end{array}$ & & $\begin{array}{l}0.0059 * * \\
(0.0018)\end{array}$ \\
\hline$C P C M_{i, j}^{k}$ & & & & & $\begin{array}{l}0.1035^{* *} \\
(0.0349)\end{array}$ & $\begin{array}{l}0.0939 * \\
(0.0375)\end{array}$ \\
\hline $\begin{array}{l}\text { Adjusted } \\
\mathrm{R}^{2}\end{array}$ & 0.5107 & 0.5427 & 0.5470 & 0.5475 & 0.5476 & 0.5607 \\
\hline
\end{tabular}

Notes: The estimation results of equation (9) for 1971-1982 are presented. For all specifications, both country dummy and sector dummy variables are included. Heteroskedasticity-robust standard errors (White, 1980) are provided in parentheses. ** and * indicate statistical significance at, respectively, the $1 \%$ and $5 \%$ levels. See the text for definitions of the variables. 
Table B1-2. The Results of the Cross-Country Relative Price Volatility Regression for 1971-1982

\begin{tabular}{|c|c|c|c|c|c|c|}
\hline & \multicolumn{6}{|c|}{ Model Specifications } \\
\hline & 7 & 8 & 9 & 10 & 11 & 12 \\
\hline Distance & $\begin{array}{l}-0.0007 \\
(0.0008)\end{array}$ & $\begin{array}{l}-0.0010 \\
(0.0008)\end{array}$ & $\begin{array}{l}-0.0010 \\
(0.0008)\end{array}$ & $\begin{array}{l}-0.0014 \\
(0.0009)\end{array}$ & $\begin{array}{l}-0.0007 \\
(0.0008)\end{array}$ & $\begin{array}{l}-0.0017^{\#} \\
(0.0009)\end{array}$ \\
\hline Exchange & $1.2222 * *$ & $1.1776^{* *}$ & $1.1174 * *$ & $1.1072 * *$ & $1.2404^{* *}$ & $1.1100 * *$ \\
\hline $\begin{array}{l}\text { Rate } \\
\text { Volatility }\end{array}$ & $(0.1320)$ & $(0.1320)$ & (0.1379) & $(0.1390)$ & $(0.1307)$ & (0.1409) \\
\hline$A P C M_{i, j}^{k}$ & $\begin{array}{l}0.0073^{* *} \\
(0.0023)\end{array}$ & $\begin{array}{l}0.0073^{* *} \\
(0.0022)\end{array}$ & $\begin{array}{l}0.0072 * * \\
(0.0022)\end{array}$ & $\begin{array}{l}0.0073^{* *} \\
(0.0022)\end{array}$ & $\begin{array}{l}0.0073^{* *} \\
(0.0023)\end{array}$ & $\begin{array}{l}0.0073 * * \\
(0.0023)\end{array}$ \\
\hline$V P C M_{i, j}^{k}$ & $\begin{array}{l}0.0059 * * \\
(0.0018)\end{array}$ & $\begin{array}{l}0.0060 * * \\
(0.0019)\end{array}$ & $\begin{array}{l}0.0060 * * \\
(0.0019)\end{array}$ & $\begin{array}{l}0.0060 * * \\
(0.0019)\end{array}$ & $\begin{array}{l}0.0059 * * \\
(0.0018)\end{array}$ & $\begin{array}{l}0.0060^{* * *} \\
(0.0019)\end{array}$ \\
\hline$C P C M_{i, j}^{k}$ & $\begin{array}{l}0.0939 * \\
(0.0374)\end{array}$ & $\begin{array}{l}0.0930^{*} \\
(0.0374)\end{array}$ & $\begin{array}{l}0.0969 * \\
(0.0377)\end{array}$ & $\begin{array}{l}0.0955^{*} \\
(0.0375)\end{array}$ & $\begin{array}{l}0.0941^{*} \\
(0.0375)\end{array}$ & $\begin{array}{l}0.0961 * \\
(0.0375)\end{array}$ \\
\hline Adjacency & $\begin{array}{l}-0.0011 \\
(0.0014)\end{array}$ & & & $\begin{array}{l}-0.0007 \\
(0.0016)\end{array}$ & & $\begin{array}{l}0.0000 \\
(0.0018)\end{array}$ \\
\hline Language & & $\begin{array}{l}-0.0042 * * \\
(0.0014)\end{array}$ & & $\begin{array}{l}-0.0028 \\
(0.0017)\end{array}$ & & $\begin{array}{l}-0.0027 \\
(0.0017)\end{array}$ \\
\hline Sea & & & $\begin{array}{l}0.0044 * \\
(0.0018)\end{array}$ & $\begin{array}{l}0.0031 \\
(0.0021)\end{array}$ & & $\begin{array}{l}0.0037 \\
(0.0022)\end{array}$ \\
\hline EEC & & & & & $\begin{array}{l}-0.0002 \\
(0.0016)\end{array}$ & $\begin{array}{l}-0.0010 \\
(0.0017)\end{array}$ \\
\hline EFTA & & & & & $\begin{array}{l}-0.0036 \\
(0.0022)\end{array}$ & $\begin{array}{l}-0.0039 \\
(0.0028)\end{array}$ \\
\hline $\begin{array}{l}\text { Adjusted } \\
\mathrm{R}^{2}\end{array}$ & 0.5606 & 0.5623 & 0.5619 & 0.5622 & 0.5605 & 0.5620 \\
\hline
\end{tabular}

Notes: The estimation results of equation (9) for 1971-1982 are presented. For all specifications, both country dummy and sector dummy variables are included. Heteroskedasticity-robust standard errors (White, 1980) are provided in parentheses. ** and * indicate statistical significance at, respectively, the $1 \%$ and $5 \%$ levels. See the text for definitions of the variables. 
Table B1-3. The Results of the Inflation Differential Variability Regression for 1971-1982

\begin{tabular}{|c|c|c|c|c|c|c|}
\hline & \multicolumn{6}{|c|}{ Model Specifications } \\
\hline & 1 & 2 & 3 & 4 & 5 & 6 \\
\hline Distance & $\begin{array}{l}0.0006 \\
(0.0005)\end{array}$ & $\begin{array}{l}0.0004 \\
(0.0006)\end{array}$ & $\begin{array}{l}0.0004 \\
(0.0006)\end{array}$ & $\begin{array}{l}0.0004 \\
(0.0006)\end{array}$ & $\begin{array}{l}0.0004 \\
(0.0006)\end{array}$ & $\begin{array}{l}0.0004 \\
(0.0006)\end{array}$ \\
\hline Exchange & & 0.0421 & 0.0419 & 0.0389 & 0.0404 & 0.0369 \\
\hline $\begin{array}{l}\text { Rate } \\
\text { Volatility }\end{array}$ & & (0.0979) & (0.0980) & $(0.0986)$ & $(0.0979)$ & (0.0983) \\
\hline$A P C M_{i, j}^{k}$ & & & $\begin{array}{l}0.0015 \\
(0.0015)\end{array}$ & & & $\begin{array}{l}0.0036^{*} \\
(0.0018)\end{array}$ \\
\hline$V P C M_{i, j}^{k}$ & & & & $\begin{array}{l}0.0031^{*} \\
(0.0014)\end{array}$ & & $\begin{array}{l}0.0041^{*} \\
(0.0016)\end{array}$ \\
\hline$C P C M_{i, j}^{k}$ & & & & & $\begin{array}{l}0.0161 \\
(0.0308)\end{array}$ & $\begin{array}{l}0.0160 \\
(0.0343)\end{array}$ \\
\hline $\begin{array}{l}\text { Adjusted } \\
\mathrm{R}^{2}\end{array}$ & 0.5467 & 0.5464 & 0.5469 & 0.5533 & 0.5463 & 0.5565 \\
\hline
\end{tabular}

Notes: The estimation results of equation (11) for 1971-1982 are presented. For all specifications, both country dummy and sector dummy variables are included. Heteroskedasticity-robust standard errors (White, 1980) are provided in parentheses. ** and * indicate statistical significance at, respectively, the $1 \%$ and $5 \%$ levels. See the text for definitions of the variables. 
Table B1-4. The Results of the Inflation Differential Variability Regression for 1971-1982

\begin{tabular}{|c|c|c|c|c|c|c|}
\hline & \multicolumn{6}{|c|}{ Model Specifications } \\
\hline & 7 & 8 & 9 & 10 & 11 & 12 \\
\hline Distance & $\begin{array}{l}0.0002 \\
(0.0006)\end{array}$ & $\begin{array}{l}0.0003 \\
(0.0006)\end{array}$ & $\begin{array}{l}0.0003 \\
(0.0006)\end{array}$ & $\begin{array}{l}0.0001 \\
(0.0007)\end{array}$ & $\begin{array}{l}0.0002 \\
(0.0006)\end{array}$ & $\begin{array}{l}-0.0000 \\
(0.0007)\end{array}$ \\
\hline Exchange & 0.0320 & 0.0285 & 0.0135 & 0.0060 & 0.0381 & 0.0000 \\
\hline $\begin{array}{l}\text { Rate } \\
\text { Volatility }\end{array}$ & $(0.0994)$ & $(0.0998)$ & $(0.1032)$ & $(0.1044)$ & $(0.0982)$ & $(0.1058)$ \\
\hline$A P C M_{i, j}^{k}$ & $\begin{array}{l}0.0036 * \\
(0.0018)\end{array}$ & $\begin{array}{l}0.0036^{*} \\
(0.0018)\end{array}$ & $\begin{array}{l}0.0036 * \\
(0.0018)\end{array}$ & $\begin{array}{l}0.0036 * \\
(0.0018)\end{array}$ & $\begin{array}{l}0.0036 * \\
(0.0018)\end{array}$ & $\begin{array}{l}0.0036^{*} \\
(0.0018)\end{array}$ \\
\hline$V P C M_{i, j}^{k}$ & $\begin{array}{l}0.0041^{*} \\
(0.0016)\end{array}$ & $\begin{array}{l}0.0041^{*} \\
(0.0016)\end{array}$ & $\begin{array}{l}0.0041^{*} \\
(0.0016)\end{array}$ & $\begin{array}{l}0.0041^{*} \\
(0.0016)\end{array}$ & $\begin{array}{l}0.0041^{*} \\
(0.0016)\end{array}$ & $\begin{array}{l}0.0041^{*} \\
(0.0016)\end{array}$ \\
\hline$C P C M_{i, j}^{k}$ & $\begin{array}{l}0.0161 \\
(0.0343)\end{array}$ & $\begin{array}{l}0.0159 \\
(0.0343)\end{array}$ & $\begin{array}{l}0.0166 \\
(0.0344)\end{array}$ & $\begin{array}{l}0.0167 \\
(0.0344)\end{array}$ & $\begin{array}{l}0.0161 \\
(0.0343)\end{array}$ & $\begin{array}{l}0.0169 \\
(0.0344)\end{array}$ \\
\hline Adjacency & $\begin{array}{l}-0.0005 \\
(0.0011)\end{array}$ & & & $\begin{array}{l}-0.0005 \\
(0.0013)\end{array}$ & & $\begin{array}{l}-0.0005 \\
(0.0014)\end{array}$ \\
\hline Language & & $\begin{array}{l}-0.0006 \\
(0.0011)\end{array}$ & & $\begin{array}{l}-0.0001 \\
(0.0014)\end{array}$ & & $\begin{array}{l}-0.0001 \\
(0.0014)\end{array}$ \\
\hline Sea & & & $\begin{array}{l}0.0009 \\
(0.0014)\end{array}$ & $\begin{array}{l}0.0009 \\
(0.0015)\end{array}$ & & $\begin{array}{l}0.0012 \\
(0.0017)\end{array}$ \\
\hline EEC & & & & & $\begin{array}{l}-0.0008 \\
(0.0012)\end{array}$ & $\begin{array}{l}-0.0010 \\
(0.0013)\end{array}$ \\
\hline EFTA & & & & & $\begin{array}{l}-0.0001 \\
(0.0017)\end{array}$ & $\begin{array}{l}0.0000 \\
(0.0021)\end{array}$ \\
\hline $\begin{array}{l}\text { Adjusted } \\
\mathrm{R}^{2}\end{array}$ & 0.5562 & 0.5563 & 0.5563 & 0.5557 & 0.5560 & 0.5552 \\
\hline
\end{tabular}

Notes: The estimation results of equation (11) for 1971-1982 are presented. For all specifications, both country dummy and sector dummy variables are included. Heteroskedasticity-robust standard errors (White, 1980) are provided in parentheses. ** and * indicate statistical significance at, respectively, the $1 \%$ and $5 \%$ levels. See the text for definitions of the variables. 
Table B1-5. The Results of Exchange Rate Change - Inflation Differential Covariance Regression 1971-1982

\begin{tabular}{|c|c|c|c|c|c|c|}
\hline & \multicolumn{6}{|c|}{ Model Specifications } \\
\hline & 1 & 2 & 3 & 4 & 5 & 6 \\
\hline Distance & $\begin{array}{l}0.0001 \\
(0.0001)\end{array}$ & $\begin{array}{l}0.0004^{*} \\
(0.0002)\end{array}$ & $\begin{array}{l}0.0004^{*} \\
(0.0001)\end{array}$ & $\begin{array}{l}0.0004^{*} \\
(0.0001)\end{array}$ & $\begin{array}{l}0.0004^{*} \\
(0.0002)\end{array}$ & $\begin{array}{l}0.0004^{*} \\
(0.0002)\end{array}$ \\
\hline Exchange & & $-0.1056^{* *}$ & $-0.1029 * *$ & $-0.1053 * *$ & $-0.1011^{*}$ & $-0.0979 *$ \\
\hline $\begin{array}{l}\text { Rate } \\
\text { Volatility }\end{array}$ & & (0.0389) & (0.0389) & (0.0389) & (0.0389) & (0.0389) \\
\hline$A P C M_{i, j}^{k}$ & & & $\begin{array}{l}-0.0020 * * \\
(0.0004)\end{array}$ & & & $\begin{array}{l}-0.0018 * * \\
(0.0005)\end{array}$ \\
\hline$V P C M_{i, j}^{k}$ & & & & $\begin{array}{l}-0.0002 \\
(0.0002)\end{array}$ & & $\begin{array}{l}-0.0009 * * \\
(0.0002)\end{array}$ \\
\hline$C P C M_{i, j}^{k}$ & & & & & $\begin{array}{l}-0.0436 * * \\
(0.0074)\end{array}$ & $\begin{array}{l}-0.0389 * * \\
(0.0074)\end{array}$ \\
\hline $\begin{array}{l}\text { Adjusted } \\
\mathrm{R}^{2}\end{array}$ & 0.1198 & 0.1253 & 0.1401 & 0.1251 & 0.1495 & 0.1617 \\
\hline
\end{tabular}

Notes: The estimation results of equation (12) for 1971-1982 are presented. For all specifications, both country dummy and sector dummy variables are included. Heteroskedasticity-robust standard errors (White, 1980) are provided in parentheses. ** and * indicate statistical significance at, respectively, the $1 \%$ and $5 \%$ levels. See the text for definitions of the variables. 
Table B1-6. The Results of Exchange Rate Change - Inflation Differential Covariance Regression for 1971-1982

\begin{tabular}{|c|c|c|c|c|c|c|}
\hline & \multicolumn{6}{|c|}{ Model Specifications } \\
\hline & 7 & 8 & 9 & 10 & 11 & 12 \\
\hline Distance & $\begin{array}{l}0.0005^{*} \\
(0.0002)\end{array}$ & $\begin{array}{l}0.0006^{* *} \\
(0.0002)\end{array}$ & $\begin{array}{l}0.0006^{* *} \\
(0.0002)\end{array}$ & $\begin{array}{l}0.0007 * * \\
(0.0002)\end{array}$ & $\begin{array}{l}0.0005^{*} \\
(0.0002)\end{array}$ & $\begin{array}{l}0.0008^{* *} \\
(0.0002)\end{array}$ \\
\hline Exchange & $-0.0950 *$ & $-0.0745^{\#}$ & -0.0519 & -0.0505 & $-0.1011^{*}$ & -0.0549 \\
\hline $\begin{array}{l}\text { Rate } \\
\text { Volatility }\end{array}$ & $(0.0394)$ & $(0.0394)$ & $(0.0413)$ & $(0.0419)$ & $(0.0390)$ & $(0.0425)$ \\
\hline$A P C M_{i, j}^{k}$ & $\begin{array}{l}-0.0018^{* *} \\
(0.0005)\end{array}$ & $\begin{array}{l}-0.0018^{* *} \\
(0.0005)\end{array}$ & $\begin{array}{l}-0.0017^{* *} \\
(0.0005)\end{array}$ & $\begin{array}{l}-0.0018^{* *} \\
(0.0005)\end{array}$ & $\begin{array}{l}-0.0018^{* *} \\
(0.0005)\end{array}$ & $\begin{array}{l}-0.0018^{* *} \\
(0.0005)\end{array}$ \\
\hline$V P C M_{i, j}^{k}$ & $\begin{array}{l}-0.0009 * * \\
(0.0002)\end{array}$ & $\begin{array}{l}-0.0009 * * \\
(0.0002)\end{array}$ & $\begin{array}{l}-0.0009 * * \\
(0.0002)\end{array}$ & $\begin{array}{l}-0.0009 * * \\
(0.0002)\end{array}$ & $\begin{array}{l}-0.0009 * * \\
(0.0002)\end{array}$ & $\begin{array}{l}-0.0009 * * \\
(0.0002)\end{array}$ \\
\hline$C P C M_{i, j}^{k}$ & $\begin{array}{l}-0.0389 * * \\
(0.0074)\end{array}$ & $\begin{array}{l}-0.0385^{* *} \\
(0.0074)\end{array}$ & $\begin{array}{l}-0.0401^{* *} \\
(0.0074)\end{array}$ & $\begin{array}{l}-0.0394^{* *} \\
(0.0074)\end{array}$ & $\begin{array}{l}-0.0390^{* * *} \\
(0.0074)\end{array}$ & $\begin{array}{l}-0.0396 * * \\
(0.0074)\end{array}$ \\
\hline Adjacency & $\begin{array}{l}0.0003 \\
(0.0003)\end{array}$ & & & $\begin{array}{l}0.0000 \\
(0.0004)\end{array}$ & & $\begin{array}{l}-0.0002 \\
(0.0004)\end{array}$ \\
\hline Language & & $\begin{array}{l}0.0017 * * \\
(0.0003)\end{array}$ & & $\begin{array}{l}0.0013^{* *} \\
(0.0004)\end{array}$ & & $\begin{array}{l}0.0013^{* *} \\
(0.0004)\end{array}$ \\
\hline Sea & & & $\begin{array}{l}-0.0017 * * \\
(0.0005)\end{array}$ & $\begin{array}{l}-0.0011^{\#} \\
(0.0006)\end{array}$ & & $\begin{array}{l}-0.0012 \\
(0.0006)\end{array}$ \\
\hline EEC & & & & & $\begin{array}{l}-0.0002 \\
(0.0004)\end{array}$ & $\begin{array}{l}0.0000 \\
(0.0004)\end{array}$ \\
\hline EFTA & & & & & $\begin{array}{l}0.0017^{* *} \\
(0.0005)\end{array}$ & $\begin{array}{l}0.0019 * * \\
(0.0007)\end{array}$ \\
\hline $\begin{array}{l}\text { Adjusted } \\
\mathrm{R}^{2}\end{array}$ & 0.1614 & 0.1701 & 0.1676 & 0.1709 & 0.1634 & 0.1942 \\
\hline
\end{tabular}

Notes: The estimation results of equation (12) for 1971-1982 are presented. For all specifications, both country dummy and sector dummy variables are included. Heteroskedasticity-robust standard errors (White, 1980) are provided in parentheses. ** and * indicate statistical significance at, respectively, the $1 \%$ and $5 \%$ levels. See the text for definitions of the variables. 


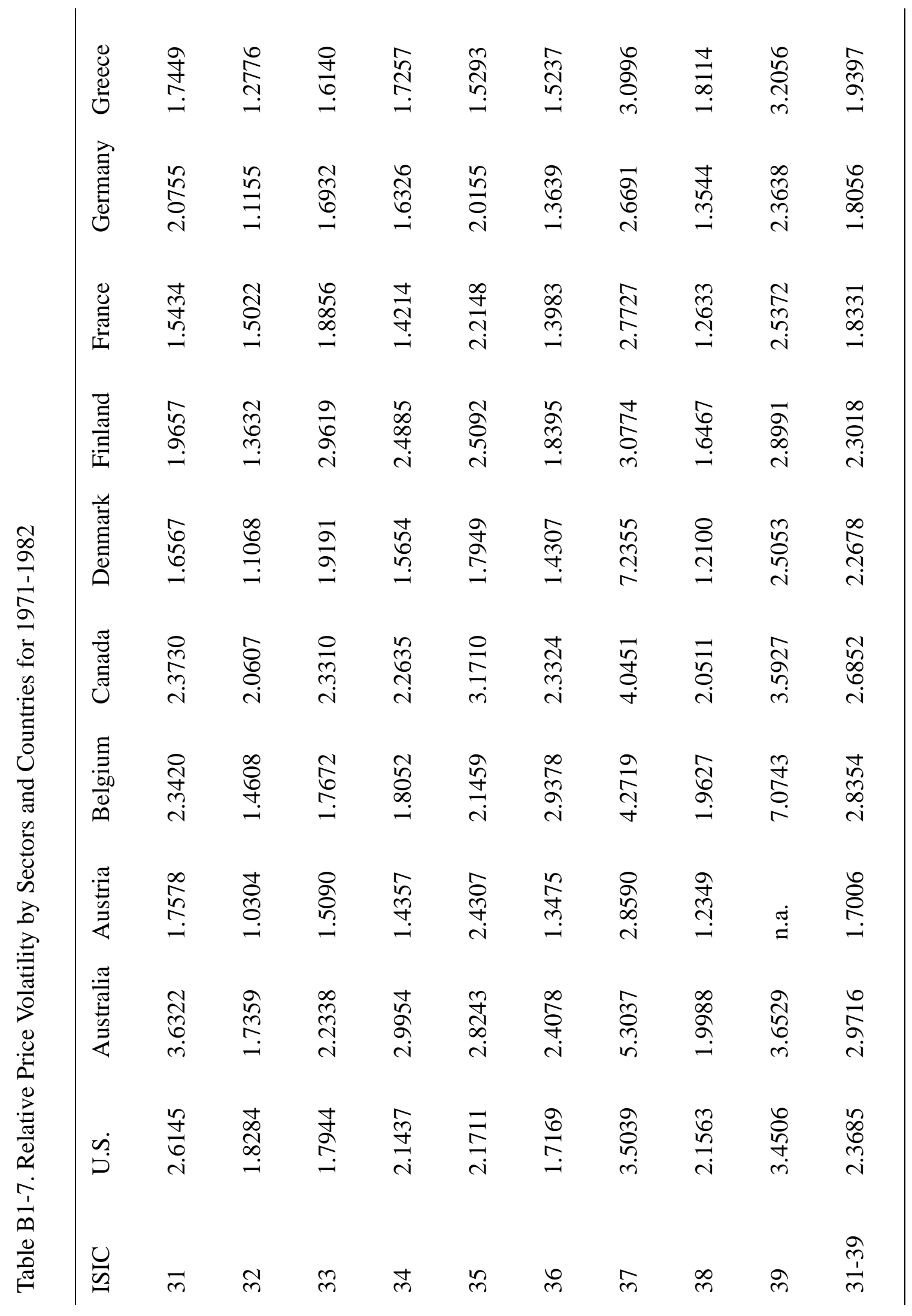




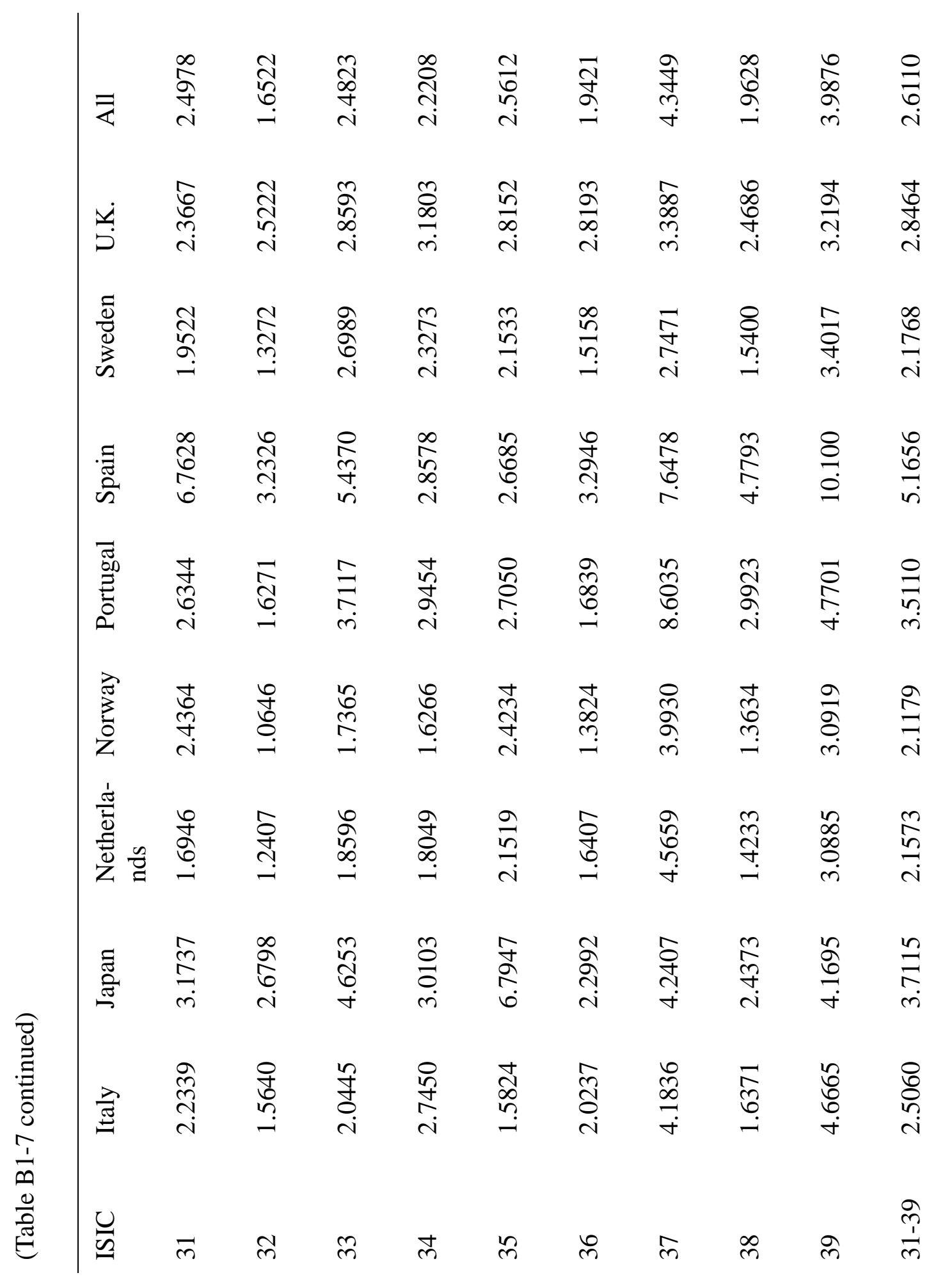

Notes: The figures represent sample variances of sectoral relative prices of the specified sectors and countries. Sectors are denoted by their international standard industry classification (ISIC) codes in the first column. 
Table B1-8. Decomposition of Cross-Country Relative Price Volatility for 1971-1982

\begin{tabular}{|c|c|c|c|c|}
\hline & $\operatorname{Var}\left(\Delta q_{i, j}^{k}\right)$ & $\frac{\operatorname{Var}\left(\Delta e_{i, j}\right)}{\operatorname{Var}\left(\Delta q_{i, j}^{k}\right)}$ & $\frac{\operatorname{Var}\left(\Delta p_{i}^{k}-\Delta p_{j}^{k}\right)}{\operatorname{Var}\left(\Delta q_{i, j}^{k}\right)}$ & $\frac{-2 \operatorname{Cov}\left(\Delta e_{i, j}, \Delta p_{i}^{k}-\Delta p_{j}^{k}\right)}{\operatorname{Var}\left(\Delta q_{i, j}^{k}\right)}$ \\
\hline $\begin{array}{l}\text { 31: Food, } \\
\text { beverages and } \\
\text { tobacco }\end{array}$ & 2.4978 & 42.2372 & 49.8283 & 7.9346 \\
\hline $\begin{array}{l}\text { 32: Textiles, } \\
\text { apparel and leather }\end{array}$ & 1.6522 & 63.8541 & 40.9605 & -4.8147 \\
\hline $\begin{array}{l}\text { 33: Wood products } \\
\text { and furniture }\end{array}$ & 2.4823 & 42.5002 & 56.8685 & 0.6311 \\
\hline $\begin{array}{l}\text { 34: Paper, paper } \\
\text { products and } \\
\text { printing }\end{array}$ & 2.2208 & 47.5052 & 49.2384 & 3.2562 \\
\hline $\begin{array}{l}\text { 35: Chemical } \\
\text { products }\end{array}$ & 2.5612 & 41.1920 & 40.9476 & 17.8603 \\
\hline $\begin{array}{l}\text { 36: Non-metallic } \\
\text { mineral products }\end{array}$ & 1.9421 & 54.3222 & 47.0798 & -1.4021 \\
\hline $\begin{array}{l}\text { 37: Basic metal } \\
\text { industries }\end{array}$ & 4.3449 & 24.2813 & 75.2895 & 0.4291 \\
\hline $\begin{array}{l}\text { 38: Fabricated } \\
\text { metal products }\end{array}$ & 1.9628 & 53.7487 & 37.1224 & 9.1288 \\
\hline $\begin{array}{l}\text { 39: Other } \\
\text { manufacturing }\end{array}$ & 3.9876 & 26.4569 & 66.7195 & 5.3362 \\
\hline 31-39: & 2.6110 & 40.4063 & 54.9553 & 4.4574 \\
\hline
\end{tabular}


B. By Country

\begin{tabular}{|c|c|c|c|c|}
\hline & $\operatorname{Var}\left(\Delta q_{i, j}^{k}\right)$ & $\frac{\operatorname{Var}\left(\Delta e_{i, j}\right)}{\operatorname{Var}\left(\Delta q_{i, j}^{k}\right)}$ & $\frac{\operatorname{Var}\left(\Delta p_{i}^{k}-\Delta p_{j}^{k}\right)}{\operatorname{Var}\left(\Delta q_{i, j}^{k}\right)}$ & $\frac{-2 \operatorname{Cov}\left(\Delta e_{i, j}, \Delta p_{i}^{k}-\Delta p_{j}^{k}\right)}{\operatorname{Var}\left(\Delta q_{i, j}^{k}\right)}$ \\
\hline U.S. & 2.3685 & 49.3546 & 41.7587 & 8.8007 \\
\hline Australia & 2.9716 & 45.7642 & 49.2430 & 5.0207 \\
\hline Austria & 1.7006 & 46.6506 & 54.4542 & -0.9821 \\
\hline Belgium & 2.8354 & 31.3296 & 60.7017 & 7.7639 \\
\hline Canada & 2.6852 & 48.7448 & 41.8437 & 9.3314 \\
\hline Denmark & 2.2678 & 33.1019 & 61.4547 & 5.2427 \\
\hline Finland & 2.3018 & 31.2392 & 61.8726 & 6.7667 \\
\hline France & 1.8331 & 43.8423 & 53.2877 & 2.7304 \\
\hline Germany & 1.8056 & 46.7649 & 50.1466 & 2.7725 \\
\hline Greece & 1.9397 & 36.8188 & 67.9206 & -4.8894 \\
\hline Italy & 2.5060 & 46.3885 & 61.0631 & -7.4237 \\
\hline Japan & 3.7115 & 56.1847 & 43.0436 & 0.7781 \\
\hline Netherlands & 2.1573 & 34.7801 & 59.2918 & 5.6715 \\
\hline Norway & 2.1179 & 33.9091 & 63.8805 & 2.0741 \\
\hline Portugal & 3.5110 & 37.5909 & 59.8208 & 2.5933 \\
\hline Spain & 5.1656 & 23.6865 & 64.4227 & 11.7885 \\
\hline Sweden & 2.1768 & 47.8355 & 49.3911 & 2.6669 \\
\hline U.K. & 2.8464 & 46.9936 & 44.6287 & 8.2956 \\
\hline All & 2.6110 & 40.4063 & 54.9553 & 4.4574 \\
\hline
\end{tabular}

Notes: Total variation is the sample variance in percentage terms of the cross-country relative price of the corresponding sectors. The relative shares denote the percentage of the specified component in the total variation. 
Table B2-1. The Results of the Cross-Country Relative Price Volatility Regression for 1983-1994

\begin{tabular}{|c|c|c|c|c|c|c|}
\hline & \multicolumn{6}{|c|}{ Model Specifications } \\
\hline & 1 & 2 & 3 & 4 & 5 & 6 \\
\hline Distance & $\begin{array}{l}0.0063 * * \\
(0.0004)\end{array}$ & $\begin{array}{l}0.0006 \\
(0.0004)\end{array}$ & $\begin{array}{l}0.0006 \\
(0.0008)\end{array}$ & $\begin{array}{l}0.0006 \\
(0.0004)\end{array}$ & $\begin{array}{l}0.0006 \\
(0.0004)\end{array}$ & $\begin{array}{l}0.0005 \\
(0.0004)\end{array}$ \\
\hline Exchange & & $1.0261^{* *}$ & $1.0262 * *$ & $1.0214^{* *}$ & $1.0178 * *$ & $1.0121^{* *}$ \\
\hline Rate & & (0.0483) & $(0.0484)$ & $(0.0480)$ & (0.0486) & (0.0483) \\
\hline Volatility & & & & & & \\
\hline$A P C M_{i, j}^{k}$ & & & $\begin{array}{l}0.0006 \\
(0.0018)\end{array}$ & & & $\begin{array}{l}0.0022 \\
(0.0018)\end{array}$ \\
\hline$V P C M_{i, j}^{k}$ & & & & $\begin{array}{l}0.0071^{* *} \\
(0.0019)\end{array}$ & & $\begin{array}{l}0.0080 * * \\
(0.0021)\end{array}$ \\
\hline$C P C M_{i, j}^{k}$ & & & & & $\begin{array}{l}0.0662 * \\
(0.0284)\end{array}$ & $\begin{array}{l}0.0720^{*} \\
(0.0288)\end{array}$ \\
\hline $\begin{array}{l}\text { Adjusted } \\
\mathrm{R}^{2}\end{array}$ & 0.5538 & 0.6692 & 0.6690 & 0.6760 & 0.6730 & 0.6809 \\
\hline
\end{tabular}

Notes: The estimation results of equation (9) for 1983-1994 are presented. For all specifications, both country dummy and sector dummy variables are included. Heteroskedasticity-robust standard errors (White, 1980) are provided in parentheses. ** and * indicate statistical significance at, respectively, the $1 \%$ and $5 \%$ levels. See the text for definitions of the variables. 
Table B2-2. The Results of the Cross-Country Relative Price Volatility Regression for 1983-1994

\begin{tabular}{|c|c|c|c|c|c|c|}
\hline & \multicolumn{6}{|c|}{ Model Specifications } \\
\hline & 7 & 8 & 9 & 10 & 11 & 12 \\
\hline Distance & $\begin{array}{l}0.0000 \\
(0.0005)\end{array}$ & $\begin{array}{l}0.0006 \\
(0.0004)\end{array}$ & $\begin{array}{l}0.0009^{\#} \\
(0.0004)\end{array}$ & $\begin{array}{l}0.0004 \\
(0.0006)\end{array}$ & $\begin{array}{l}-0.0002 \\
(0.0005)\end{array}$ & $\begin{array}{l}-0.0000 \\
(0.0006)\end{array}$ \\
\hline Exchange & $1.0180 * *$ & $1.0174 * *$ & $1.0949 * *$ & $1.0980 * *$ & $1.0166^{* *}$ & $1.0759 * *$ \\
\hline $\begin{array}{l}\text { Rate } \\
\text { Volatility }\end{array}$ & $(0.0492)$ & $(0.0514)$ & $(0.0575)$ & $(0.0608)$ & $(0.0489)$ & $(0.0611)$ \\
\hline$A P C M_{i, j}^{k}$ & $\begin{array}{l}0.0022 \\
(0.0018)\end{array}$ & $\begin{array}{l}0.0022 \\
(0.0018)\end{array}$ & $\begin{array}{l}0.0022 \\
(0.0018)\end{array}$ & $\begin{array}{l}0.0022 \\
(0.0018)\end{array}$ & $\begin{array}{l}0.0022 \\
(0.0018)\end{array}$ & $\begin{array}{l}0.0022 \\
(0.0018)\end{array}$ \\
\hline$V P C M_{i, j}^{k}$ & $\begin{array}{l}0.0080^{* *} \\
(0.0021)\end{array}$ & $\begin{array}{l}0.0080^{* *} \\
(0.0021)\end{array}$ & $\begin{array}{l}0.0080^{* *} \\
(0.0021)\end{array}$ & $\begin{array}{l}0.0080^{* *} \\
(0.0021)\end{array}$ & $\begin{array}{l}0.0080^{* *} \\
(0.0021)\end{array}$ & $\begin{array}{l}0.0080^{* * *} \\
(0.0021)\end{array}$ \\
\hline$C P C M_{i, j}^{k}$ & $\begin{array}{l}0.0729 * \\
(0.0285)\end{array}$ & $\begin{array}{l}0.0720^{*} \\
(0.0287)\end{array}$ & $\begin{array}{l}0.0730 * \\
(0.0286)\end{array}$ & $\begin{array}{l}0.0738^{* *} \\
(0.0284)\end{array}$ & $\begin{array}{l}0.0722^{*} \\
(0.0288)\end{array}$ & $\begin{array}{l}0.0732 * \\
(0.0286)\end{array}$ \\
\hline Adjacency & $\begin{array}{l}-0.0014^{\#} \\
(0.0007)\end{array}$ & & & $\begin{array}{l}-0.0013 \\
(0.0016)\end{array}$ & & $\begin{array}{l}-0.0006 \\
(0.0007)\end{array}$ \\
\hline Language & & $\begin{array}{l}0.0003 \\
(0.0009)\end{array}$ & & $\begin{array}{l}-0.0017 \\
(0.0009)\end{array}$ & & $\begin{array}{l}-0.0000 \\
(0.0009)\end{array}$ \\
\hline Sea & & & $\begin{array}{l}-0.0036^{* *} \\
(0.0012)\end{array}$ & $\begin{array}{l}-0.0036^{* *} \\
(0.0011)\end{array}$ & & $\begin{array}{l}-0.0025^{*} \\
(0.0012)\end{array}$ \\
\hline EEC & & & & & $\begin{array}{l}-0.0031 * * \\
(0.0008)\end{array}$ & $\begin{array}{l}-0.0025^{* *} \\
(0.0009)\end{array}$ \\
\hline EFTA & & & & & $\begin{array}{l}-0.0039 * \\
(0.0015)\end{array}$ & $\begin{array}{l}-0.0032 * \\
(0.0016)\end{array}$ \\
\hline $\begin{array}{l}\text { Adjusted } \\
\mathrm{R}^{2}\end{array}$ & 0.6813 & 0.6807 & 0.6830 & 0.6832 & 0.6847 & 0.6851 \\
\hline
\end{tabular}

Notes: The estimation results of equation (9) for 1983-1994 are presented. For all specifications, both country dummy and sector dummy variables are included. Heteroskedasticity-robust standard errors (White, 1980) are provided in parentheses. ** and * indicate statistical significance at, respectively, the $1 \%$ and $5 \%$ levels. See the text for definitions of the variables. 
Table B2-3. The Results of the Inflation Differential Variability Regression for 1983-1994

\begin{tabular}{lllllll}
\hline \multicolumn{5}{c}{ Model Specifications } \\
& 1 & 2 & 3 & 4 & 5 & 6 \\
\hline Distance & 0.0001 & 0.0002 & 0.0002 & 0.0001 & 0.0002 & 0.0001 \\
& $(0.0002)$ & $(0.0003)$ & $(0.0003)$ & $(0.0003)$ & $(0.0003)$ & $(0.0003)$ \\
Exchange & & -0.0068 & -0.0065 & -0.0111 & -0.0104 & -0.0153 \\
Rate & & $(0.0354)$ & $(0.0355)$ & $(0.0349)$ & $(0.0357)$ & $(0.0352)$ \\
Volatility & & & $0.0024^{*}$ & & & $0.0040^{* *}$ \\
APCM $_{i, j}^{k}$ & & & $(0.0015)$ & & & $(0.0014)$ \\
& & & $0.0063^{* *}$ & & $0.0074^{* *}$ \\
$\operatorname{VPCM}_{i, j}^{k}$ & & & & $(0.0017)$ & 0.0285 & $(0.0017)$ \\
CPCM $_{i, j}^{k}$ & & & & & $(0.0224)$ & $(0.0216)$ \\
Adjusted & 0.5446 & 0.5443 & 0.5458 & 0.5569 & 0.5456 & 0.5634 \\
$\mathrm{R}^{2}$ & & & & & & \\
\hline
\end{tabular}

Notes: The estimation results of equation (11) for 1983-1994 are presented. For all specifications, both country dummy and sector dummy variables are included. Heteroskedasticity-robust standard errors (White, 1980) are provided in parentheses. ** and * indicate statistical significance at, respectively, the $1 \%$ and $5 \%$ levels. See the text for definitions of the variables. 
Table B2-4. The Results of the Inflation Differential Variability Regression for 1983-1994

\begin{tabular}{|c|c|c|c|c|c|c|}
\hline & \multicolumn{6}{|c|}{ Model Specifications } \\
\hline & 7 & 8 & 9 & 10 & 11 & 12 \\
\hline Distance & $\begin{array}{l}-0.0001 \\
(0.0004)\end{array}$ & $\begin{array}{l}0.0001 \\
(0.0003)\end{array}$ & $\begin{array}{l}0.0001 \\
(0.0003)\end{array}$ & $\begin{array}{l}-0.0001 \\
(0.0004)\end{array}$ & $\begin{array}{l}-0.0000 \\
(0.0004)\end{array}$ & $\begin{array}{l}-0.0003 \\
(0.0005)\end{array}$ \\
\hline Exchange & -0.0120 & -0.0173 & -0.0246 & -0.0181 & -0.0098 & -0.0196 \\
\hline $\begin{array}{l}\text { Rate } \\
\text { Volatility }\end{array}$ & $(0.0357)$ & $(0.0375)$ & $(0.0390)$ & $(0.0414)$ & $(0.0362)$ & $(0.0419)$ \\
\hline$A P C M_{i, j}^{k}$ & $\begin{array}{l}0.0040^{* *} \\
(0.0014)\end{array}$ & $\begin{array}{l}0.0040^{* *} \\
(0.0014)\end{array}$ & $\begin{array}{l}0.0040^{* *} \\
(0.0014)\end{array}$ & $\begin{array}{l}0.0040^{* *} \\
(0.0014)\end{array}$ & $\begin{array}{l}0.0040^{* *} \\
(0.0014)\end{array}$ & $\begin{array}{l}0.0040^{* *} \\
(0.0014)\end{array}$ \\
\hline$V P C M_{i, j}^{k}$ & $\begin{array}{l}0.0074 * * \\
(0.0017)\end{array}$ & $\begin{array}{l}0.0074^{* *} \\
(0.0017)\end{array}$ & $\begin{array}{l}0.0074^{* *} \\
(0.0017)\end{array}$ & $\begin{array}{l}0.0074 * * \\
(0.0017)\end{array}$ & $\begin{array}{l}0.0074 * * \\
(0.0017)\end{array}$ & $\begin{array}{l}0.0074^{* *} \\
(0.0017)\end{array}$ \\
\hline$C P C M_{i, j}^{k}$ & $\begin{array}{l}0.0335 \\
(0.0214)\end{array}$ & $\begin{array}{l}0.0330 \\
(0.0216)\end{array}$ & $\begin{array}{l}0.0329 \\
(0.0216)\end{array}$ & $\begin{array}{l}0.0335 \\
(0.0344)\end{array}$ & $\begin{array}{l}0.0340 \\
(0.0215)\end{array}$ & $\begin{array}{l}0.0340 \\
(0.0215)\end{array}$ \\
\hline Adjacency & $\begin{array}{l}-0.0008 \\
(0.0006)\end{array}$ & & & $\begin{array}{l}-0.0009 \\
(0.0006)\end{array}$ & & $\begin{array}{l}-0.0006 \\
(0.0006)\end{array}$ \\
\hline Language & & $\begin{array}{l}-0.0001 \\
(0.0005)\end{array}$ & & $\begin{array}{l}0.0004 \\
(0.0006)\end{array}$ & & $\begin{array}{l}0.0004 \\
(0.0006)\end{array}$ \\
\hline Sea & & & $\begin{array}{l}0.0004 \\
(0.0007)\end{array}$ & $\begin{array}{l}0.0006 \\
(0.0007)\end{array}$ & & $\begin{array}{l}0.0008 \\
(0.0008)\end{array}$ \\
\hline EEC & & & & & $\begin{array}{l}-0.0003 \\
(0.0006)\end{array}$ & $\begin{array}{l}-0.0004 \\
(0.0007)\end{array}$ \\
\hline EFTA & & & & & $\begin{array}{l}-0.0018 \\
(0.0012)\end{array}$ & $\begin{array}{l}-0.0015 \\
(0.0013)\end{array}$ \\
\hline $\begin{array}{l}\text { Adjusted } \\
\mathrm{R}^{2}\end{array}$ & 0.5636 & 0.5631 & 0.5632 & 0.5631 & 0.5635 & 0.5630 \\
\hline
\end{tabular}

Notes: The estimation results of equation (11) for 1983-1994 are presented. For all specifications, both country dummy and sector dummy variables are included. Heteroskedasticity-robust standard errors (White, 1980) are provided in parentheses. ** and * indicate statistical significance at, respectively, the $1 \%$ and $5 \%$ levels. See the text for definitions of the variables. 
Table B2-5. The Results of Exchange Rate Change - Inflation Differential Covariance Regression for 1983-1994

\begin{tabular}{|c|c|c|c|c|c|c|}
\hline & \multicolumn{6}{|c|}{ Model Specifications } \\
\hline & 1 & 2 & 3 & 4 & 5 & 6 \\
\hline Distance & $\begin{array}{l}-0.0003^{* *} \\
(0.0001)\end{array}$ & $\begin{array}{l}-0.0002 \\
(0.0001)\end{array}$ & $\begin{array}{l}-0.0002 \\
(0.0001)\end{array}$ & $\begin{array}{l}-0.0002 \\
(0.0001)\end{array}$ & $\begin{array}{l}-0.0002 \\
(0.0001)\end{array}$ & $\begin{array}{l}-0.0002 \\
(0.0001)\end{array}$ \\
\hline Exchange & & -0.0165 & -0.0163 & -0.0162 & -0.0141 & -0.0137 \\
\hline Rate & & $(0.0185)$ & $(0.0185)$ & $(0.0185)$ & $(0.0185)$ & $(0.0185)$ \\
\hline Volatility & & & & & & \\
\hline$A P C M_{i, j}^{k}$ & & & $\begin{array}{l}0.0009 \\
(0.0005)\end{array}$ & & & $\begin{array}{l}0.0009 \\
(0.0006)\end{array}$ \\
\hline$V P C M_{i, j}^{k}$ & & & & $\begin{array}{l}-0.0003 \\
(0.0006)\end{array}$ & & $\begin{array}{l}-0.0002 \\
(0.0007)\end{array}$ \\
\hline$C P C M_{i, j}^{k}$ & & & & & $\begin{array}{l}-0.0188 * \\
(0.0085)\end{array}$ & $\begin{array}{l}-0.0194 * \\
(0.0088)\end{array}$ \\
\hline $\begin{array}{l}\text { Adjusted } \\
\mathrm{R}^{2}\end{array}$ & 0.2254 & 0.2253 & 0.2269 & 0.2251 & 0.2468 & 0.2322 \\
\hline
\end{tabular}

Notes: The estimation results of equation (12) for 1983-1994 are presented. For all specifications, both country dummy and sector dummy variables are included. Heteroskedasticity-robust standard errors (White, 1980) are provided in parentheses. ** and * indicate statistical significance at, respectively, the $1 \%$ and $5 \%$ levels. See the text for definitions of the variables. 
Table B2-6. The Results of Exchange Rate Change - Inflation Differential Covariance Regression for 1983-1994

\begin{tabular}{|c|c|c|c|c|c|c|}
\hline & \multicolumn{6}{|c|}{ Model Specifications } \\
\hline & 7 & 8 & 9 & 10 & 11 & 12 \\
\hline Distance & $\begin{array}{l}-0.0001 \\
(0.0001)\end{array}$ & $\begin{array}{l}-0.0002 \\
(0.0002)\end{array}$ & $\begin{array}{l}-0.0003^{* *} \\
(0.0001)\end{array}$ & $\begin{array}{l}-0.0003^{\#} \\
(0.0002)\end{array}$ & $\begin{array}{l}0.0000 \\
(0.0001)\end{array}$ & $\begin{array}{l}-0.0001 \\
(0.0001)\end{array}$ \\
\hline $\begin{array}{l}\text { Exchange } \\
\text { Rate }\end{array}$ & $\begin{array}{l}-0.0150 \\
(0.0187)\end{array}$ & $\begin{array}{l}-0.0173 \\
(0.0192)\end{array}$ & $\begin{array}{l}-0.0597^{* *} \\
(0.0214)\end{array}$ & $\begin{array}{l}-0.0581^{* *} \\
(0.0222)\end{array}$ & $\begin{array}{l}-0.0132 \\
(0.0183)\end{array}$ & $\begin{array}{l}-0.0478^{*} \\
(0.0224)\end{array}$ \\
\hline Volatility & & & & & & \\
\hline$A P C M_{i, j}^{k}$ & $\begin{array}{l}0.0009 \\
(0.0006)\end{array}$ & $\begin{array}{l}0.0009 \\
(0.0006)\end{array}$ & $\begin{array}{l}0.0009 \\
(0.0006)\end{array}$ & $\begin{array}{l}0.0009 \\
(0.0006)\end{array}$ & $\begin{array}{l}0.0009 \\
(0.0006)\end{array}$ & $\begin{array}{l}0.0009 \\
(0.0006)\end{array}$ \\
\hline$V P C M_{i, j}^{k}$ & $\begin{array}{l}-0.0002 \\
(0.0007)\end{array}$ & $\begin{array}{l}-0.0002 \\
(0.0007)\end{array}$ & $\begin{array}{l}-0.0002 \\
(0.0007)\end{array}$ & $\begin{array}{l}-0.0002 \\
(0.0007)\end{array}$ & $\begin{array}{l}-0.0002 \\
(0.0007)\end{array}$ & $\begin{array}{l}-0.0003 \\
(0.0007)\end{array}$ \\
\hline$C P C M_{i, j}^{k}$ & $\begin{array}{l}-0.0196 * \\
(0.0088)\end{array}$ & $\begin{array}{l}-0.0195^{*} \\
(0.0088)\end{array}$ & $\begin{array}{l}-0.0200^{*} \\
(0.0088)\end{array}$ & $\begin{array}{l}-0.0201^{* *} \\
(0.0088)\end{array}$ & $\begin{array}{l}0.0191^{*} \\
(0.0088)\end{array}$ & $\begin{array}{l}0.0196^{*} \\
(0.0088)\end{array}$ \\
\hline $\mathrm{ADJ}$ & $\begin{array}{l}0.0003 \\
(0.0002)\end{array}$ & & & $\begin{array}{l}0.0001 \\
(0.0002)\end{array}$ & & $\begin{array}{l}-0.0000 \\
(0.0002)\end{array}$ \\
\hline Adjacency & & $\begin{array}{l}-0.0002 \\
(0.0003)\end{array}$ & & $\begin{array}{l}0.0003 \\
(0.0003)\end{array}$ & & $\begin{array}{l}0.0002 \\
(0.0003)\end{array}$ \\
\hline Language & & & $\begin{array}{l}0.0020 * * \\
(0.0004)\end{array}$ & $\begin{array}{l}0.0021^{* *} \\
(0.0004)\end{array}$ & & $\begin{array}{l}0.0017^{* *} \\
(0.0004)\end{array}$ \\
\hline Sea & & & & & $\begin{array}{l}0.0013^{* *} \\
(0.0002)\end{array}$ & $\begin{array}{l}0.0010^{* *} \\
(0.0002)\end{array}$ \\
\hline EEC & & & & & $\begin{array}{l}0.0010^{*} \\
(0.0004)\end{array}$ & $\begin{array}{l}0.0008^{\#} \\
(0.0004)\end{array}$ \\
\hline EFTA & 0.2323 & 0.2319 & 0.2455 & 0.2452 & 0.2439 & 0.2505 \\
\hline
\end{tabular}

Notes: The estimation results of equation (12) for 1983-1994 are presented. For all specifications, both country dummy and sector dummy variables are included. Heteroskedasticity-robust standard errors (White, 1980) are provided in parentheses. ** and * indicate statistical significance at, respectively, the $1 \%$ and $5 \%$ levels. See the text for definitions of the variables. 


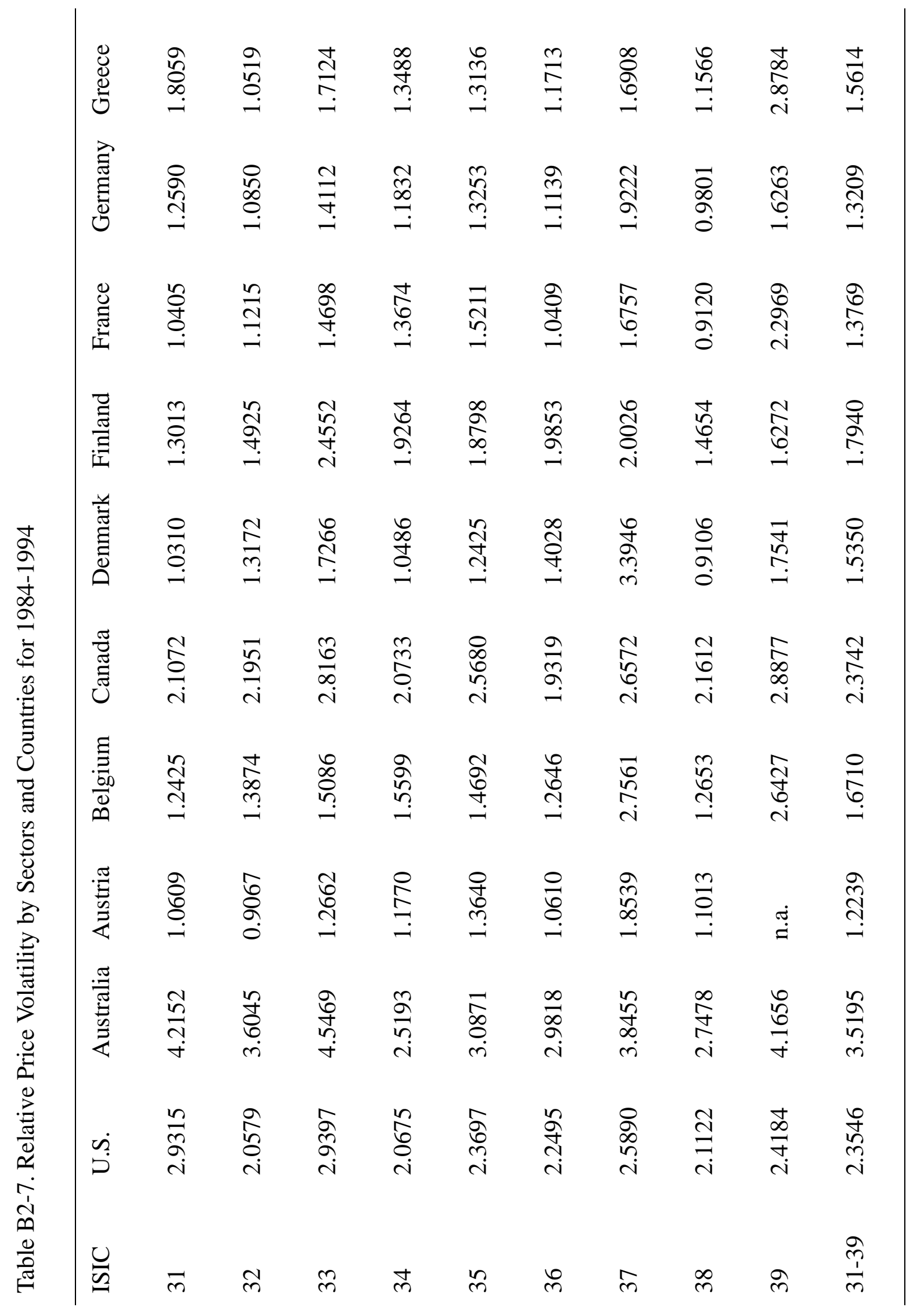




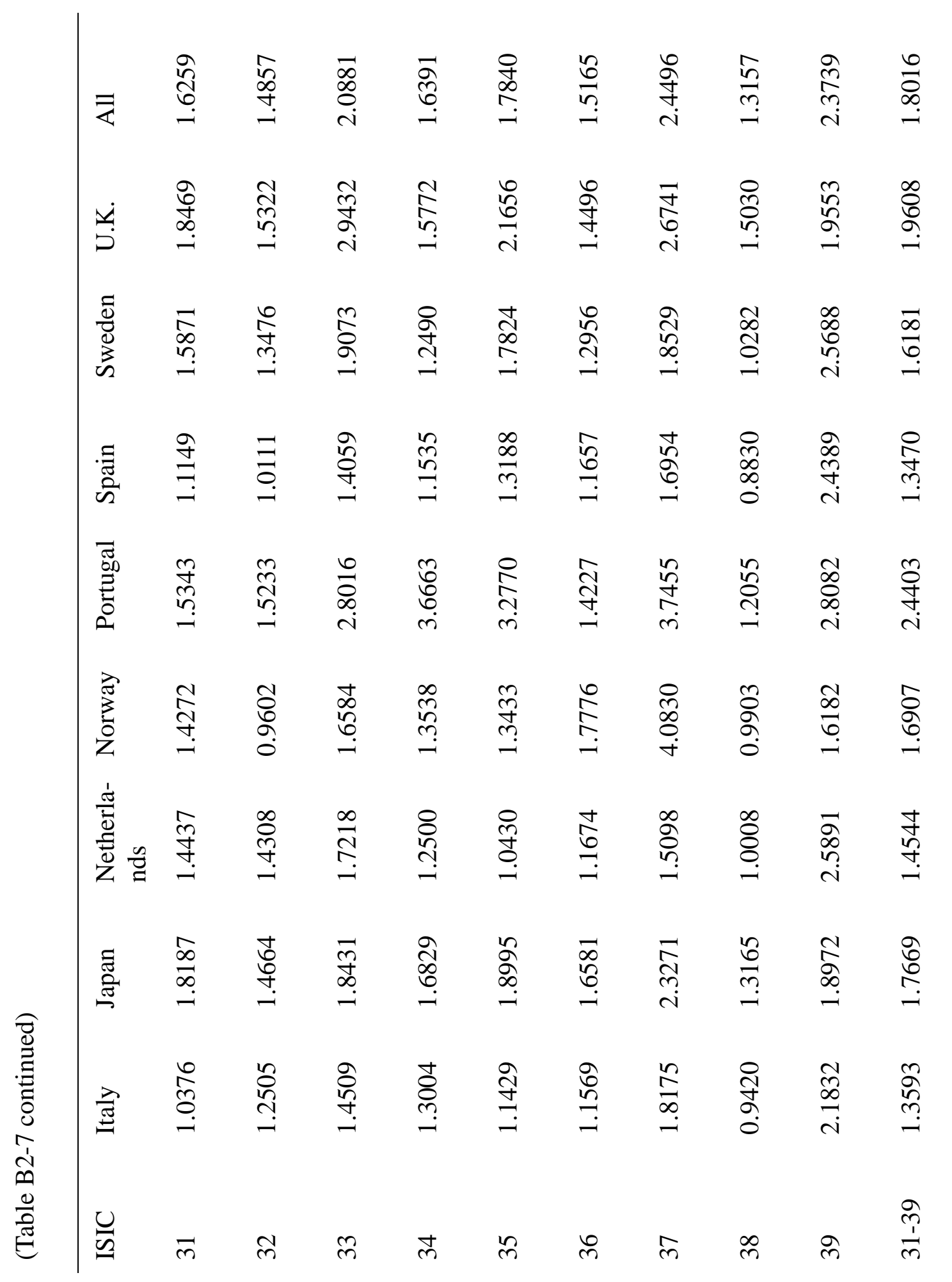

Notes: The figures represent sample variances of sectoral relative prices of the specified sectors and countries. Sectors are denoted by their international standard industry classification (ISIC) codes in the first column. 
Table B2-8. Decomposition of Cross-Country Relative Price Volatility for 1983-1994

\begin{tabular}{|c|c|c|c|c|}
\hline & \multirow[t]{2}{*}{$\operatorname{Var}\left(\Delta q_{i, j}^{k}\right)$} & $\operatorname{Var}\left(\Delta e_{i, j}\right)$ & $\operatorname{Var}\left(\Delta p_{i}^{k}-\Delta p_{j}^{k}\right)$ & $-2 \operatorname{Cov}\left(\Delta e_{i, j}, \Delta p_{i}^{k}-\Delta p_{j}^{k}\right)$ \\
\hline & & $\operatorname{Var}\left(\Delta q_{i, j}^{k}\right)$ & $\operatorname{Var}\left(\Delta q_{i, j}^{k}\right)$ & $\operatorname{Var}\left(\Delta q_{i, j}^{k}\right)$ \\
\hline $\begin{array}{l}\text { 31: Food, } \\
\text { beverages and } \\
\text { tobacco }\end{array}$ & 1.6259 & 69.4770 & 26.8677 & 3.6516 \\
\hline $\begin{array}{l}\text { 32: Textiles, } \\
\text { apparel and leather }\end{array}$ & 1.4857 & 76.0337 & 25.1461 & -1.1798 \\
\hline $\begin{array}{l}\text { 33: Wood products } \\
\text { and furniture }\end{array}$ & 2.0881 & 54.0982 & 31.8582 & 14.0435 \\
\hline $\begin{array}{l}\text { 34: Paper, paper } \\
\text { products and } \\
\text { printing }\end{array}$ & 1.6391 & 68.9146 & 39.8439 & -8.7586 \\
\hline $\begin{array}{l}\text { 35: Chemical } \\
\text { products }\end{array}$ & 1.7840 & 63.3172 & 45.5482 & -8.8654 \\
\hline $\begin{array}{l}\text { 36: Non-metallic } \\
\text { mineral products }\end{array}$ & 1.5165 & 74.4890 & 26.8640 & -1.3530 \\
\hline $\begin{array}{l}\text { 37: Basic metal } \\
\text { industries }\end{array}$ & 2.4496 & 46.1137 & 67.5898 & -13.7036 \\
\hline $\begin{array}{l}\text { 38: Fabricated } \\
\text { metal products }\end{array}$ & 1.3157 & 85.8577 & 18.2027 & -4.0604 \\
\hline $\begin{array}{l}\text { 39: Other } \\
\text { manufacturing }\end{array}$ & 2.3739 & 47.5846 & 51.36529 & -0.6477 \\
\hline 31-39: & 1.8016 & 62.6984 & 39.5123 & -2.4150 \\
\hline
\end{tabular}


B. By Country

\begin{tabular}{|c|c|c|c|c|}
\hline & $\operatorname{Var}\left(\Delta q_{i, j}^{k}\right)$ & $\frac{\operatorname{Var}\left(\Delta e_{i, j}\right)}{\operatorname{Var}\left(\Delta q_{i, j}^{k}\right)}$ & $\frac{\operatorname{Var}\left(\Delta p_{i}^{k}-\Delta p_{j}^{k}\right)}{\operatorname{Var}\left(\Delta q_{i, j}^{k}\right)}$ & $\frac{-2 \operatorname{Cov}\left(\Delta e_{i, j}, \Delta p_{i}^{k}-\Delta p_{j}^{k}\right)}{\operatorname{Var}\left(\Delta q_{i, j}^{k}\right)}$ \\
\hline U.S. & 2.3546 & 80.4189 & 21.3696 & -1.7444 \\
\hline Australia & 3.5195 & 74.4714 & 26.8531 & -1.1943 \\
\hline Austria & 1.2239 & 64.6951 & 38.7483 & -3.0609 \\
\hline Belgium & 1.6710 & 46.9314 & 46.2879 & 6.4440 \\
\hline Canada & 2.3742 & 77.9509 & 28.2192 & -6.0573 \\
\hline Denmark & 1.5350 & 49.6259 & 46.2527 & 3.7824 \\
\hline Finland & 1.7940 & 57.4051 & 41.0171 & 1.4336 \\
\hline France & 1.3769 & 59.4371 & 36.8070 & 3.3781 \\
\hline Germany & 1.3209 & 61.5833 & 34.9869 & 3.0119 \\
\hline Greece & 1.5614 & 64.3160 & 46.9525 & -11.2965 \\
\hline Italy & 1.3593 & 64.9607 & 36.4946 & -1.7323 \\
\hline Japan & 1.7669 & 74.6463 & 27.9622 & -2.7329 \\
\hline Netherlands & 1.4544 & 56.5937 & 45.6510 & -2.5931 \\
\hline Norway & 1.6907 & 44.0346 & 53.2479 & 2.6087 \\
\hline Portugal & 2.4403 & 49.3370 & 75.7356 & -25.0540 \\
\hline Spain & 1.3470 & 65.3413 & 44.2342 & -9.7136 \\
\hline Sweden & 1.6181 & 52.5839 & 43.1499 & 4.1223 \\
\hline U.K. & 1.9608 & 64.2311 & 29.4943 & 6.1600 \\
\hline All & 1.8016 & 62.6984 & 39.5123 & -2.4150 \\
\hline
\end{tabular}

Notes: Total variation is the sample variance in percentage terms of the cross-country relative price of the corresponding sectors. The relative shares denote the percentage of the specified component in the total variation. 
Appendix C

Results from the "new” and "old” industry classification schemes C1: 1971-1994, ISIC Revision 2

C2: 1971-1998, ISIC Revision 3 
Table C1-1. The Results of the Cross-Country Relative Price Volatility Regression: 9-Country Sample under the ISIC Revision 2, 1971-1994

\begin{tabular}{|c|c|c|c|c|c|c|}
\hline & \multicolumn{6}{|c|}{ Model Specifications } \\
\hline & 1 & 2 & 3 & 4 & 5 & 6 \\
\hline Distance & $\begin{array}{l}0.0020^{\#} \\
(0.0011)\end{array}$ & $\begin{array}{l}-0.0003 \\
(0.0011)\end{array}$ & $\begin{array}{l}-0.0003 \\
(0.0011)\end{array}$ & $\begin{array}{l}-0.0004 \\
(0.0010)\end{array}$ & $\begin{array}{l}-0.0003 \\
(0.0011)\end{array}$ & $\begin{array}{l}-0.0003 \\
(0.0009)\end{array}$ \\
\hline $\begin{array}{l}\text { Exchange } \\
\text { Rate }\end{array}$ & & $\begin{array}{l}1.3494^{* *} \\
(0.1987)\end{array}$ & $\begin{array}{l}1.4751^{* *} \\
(0.1878)\end{array}$ & $\begin{array}{l}1.4419 * * \\
(0.1947)\end{array}$ & $\begin{array}{l}1.3437^{* *} \\
(0.1898)\end{array}$ & $\begin{array}{l}1.5533^{* *} \\
(0.1879)\end{array}$ \\
\hline Volatility & & & & & & \\
\hline$A P C M_{i, j}^{k}$ & & & $\begin{array}{l}0.0055 \\
(0.0036)\end{array}$ & & & $\begin{array}{l}0.0117^{* *} \\
(0.0040)\end{array}$ \\
\hline$V P C M_{i, j}^{k}$ & & & & $\begin{array}{l}0.0126^{* *} \\
(0.0041)\end{array}$ & & $\begin{array}{l}0.0243^{* *} \\
(0.0062)\end{array}$ \\
\hline$C P C M_{i, j}^{k}$ & & & & & $\begin{array}{l}0.0052 \\
(0.0730)\end{array}$ & $\begin{array}{l}0.0404 \\
(0.0795)\end{array}$ \\
\hline $\begin{array}{l}\text { Adjusted } \\
\mathrm{R}^{2}\end{array}$ & 0.4164 & 0.4895 & 0.4905 & 0.5339 & 0.4878 & 0.5927 \\
\hline
\end{tabular}

Notes: The estimation results of equation (9) using the data under ISIC Revision 2 are presented. The sample consists of Belgium, Canada, Denmark, Finland, Italy, Japan, Netherlands, Norway, and the U.K The sample period is 1971-1994. For all specifications, both country dummy and sector dummy variables are included. Heteroskedasticity-robust standard errors (White, 1980) are provided in parentheses. ${ }^{* *}$ and $*$ indicate statistical significance at, respectively, the $1 \%$ and $5 \%$ levels. See the text for definitions of the variables. 
Table C1-2. The Results of the Cross-Country Relative Price Volatility Regression: 9-Country Sample under the ISIC Revision 2, 1971-1994

\begin{tabular}{lllllll}
\hline & 7 & 8 & 9 & 10 & 11 & 12 \\
\hline Distance & -0.0011 & -0.0007 & -0.0002 & -0.0010 & -0.0007 & -0.0005 \\
& $(0.0011)$ & $(0.0009)$ & $(0.0009)$ & $(0.0011)$ & $(0.0011)$ & $(0.0014)$ \\
Exchange & $1.4828^{* *}$ & $1.5377^{* *}$ & $1.7004^{* *}$ & $1.7009^{* *}$ & $1.5275^{* *}$ & $1.7963^{* *}$ \\
Rate & $(0.1944)$ & $(0.1880)$ & $(0.2175)$ & $(0.2281)$ & $(0.1943)$ & $(0.2758)$ \\
Volatility & & & & & & \\
APCM $_{i, j}^{k}$ & $0.0118^{* *}$ & $0.0116^{* *}$ & $0.0109^{* *}$ & $0.0105^{*}$ & $0.0116^{* *}$ & $0.0100^{*}$ \\
& $(0.0040)$ & $(0.0040)$ & $(0.0040)$ & $(0.0041)$ & $(0.0040)$ & $(0.0041)$ \\
VPCM $_{i, j}^{k}$ & $0.0243^{* *}$ & $0.0242^{* *}$ & $0.0240^{* *}$ & $0.0238^{* *}$ & $0.0242^{* *}$ & $0.0236^{* *}$ \\
& $(0.0061)$ & $(0.0062)$ & $(0.0062)$ & $(0.0061)$ & $(0.0061)$ & $(0.0061)$ \\
CPCM $_{i, j}^{k}$ & 0.0329 & 0.0351 & 0.0503 & 0.0445 & 0.0389 & 0.0541 \\
& $(0.0790)$ & $(0.0795)$ & $(0.0787)$ & $(0.0778)$ & $(0.0785)$ & $(0.0762)$ \\
Adjacency & $-0.0037 \#$ & & & -0.0017 & & 0.0037 \\
& $(0.0020)$ & & & $(0.0025)$ & & $(0.0042)$ \\
Language & & $-0.0034^{*}$ & & $-0.0036 \#$ & & $-0.0059^{*}$ \\
& & $(0.0015)$ & & $(0.0021)$ & & $(0.0025)$ \\
Sea & & & -0.0022 & $-0.0029 \#$ & & $-0.0035 \#$ \\
& & & $(0.0016)$ & $(0.0017)$ & & $(0.0020)$ \\
EEC & & & & & -0.0003 & 0.0002 \\
& & & & & $(0.0021)$ & $(0.0024)$ \\
EFTA & & & & -0.0039 & $-0.0072 \#$ \\
Adjusted & 0.5947 & 0.5950 & 0.5934 & 0.5967 & 0.5925 & $0.0043)$ \\
$\mathrm{R}^{2}$ & & & & & 0.5965 \\
\hline
\end{tabular}

Notes: The estimation results of equation (9) using the data under ISIC Revision 2 are presented. The sample consists of Belgium, Canada, Denmark, Finland, Italy, Japan, Netherlands, Norway, and the U.K The sample period is 1971-1994. For all specifications, both country dummy and sector dummy variables are included. Heteroskedasticity-robust standard errors (White, 1980) are provided in parentheses. ${ }^{* *}$ and $*$ indicate statistical significance at, respectively, the $1 \%$ and $5 \%$ levels. See the text for definitions of the variables. 
Table C1-3. The Results of the Inflation Differential Variability Regression: 9-Country Sample under the ISIC Revision 2, 1971-1994

\begin{tabular}{|c|c|c|c|c|c|c|}
\hline & \multicolumn{6}{|c|}{ Model Specifications } \\
\hline & 1 & 2 & 3 & 4 & 5 & 6 \\
\hline Distance & $\begin{array}{l}0.0002 \\
(0.0007)\end{array}$ & $\begin{array}{l}0.0002 \\
(0.0008)\end{array}$ & $\begin{array}{l}0.0000 \\
(0.0008)\end{array}$ & $\begin{array}{l}0.0001 \\
(0.0007)\end{array}$ & $\begin{array}{l}0.0001 \\
(0.0008)\end{array}$ & $\begin{array}{l}0.0000 \\
(0.0006)\end{array}$ \\
\hline Exchange & & -0.0099 & 0.0902 & 0.0777 & 0.0560 & $0.2096 \#$ \\
\hline $\begin{array}{l}\text { Rate } \\
\text { Volatility }\end{array}$ & & (0.1529) & (0.1279) & $(0.1438)$ & & \\
\hline$A P C M_{i, j}^{k}$ & & & $\begin{array}{l}0.0012 \\
(0.0026)\end{array}$ & & & $\begin{array}{l}0.0067^{*} \\
(0.0029)\end{array}$ \\
\hline$V P C M_{i, j}^{k}$ & & & & $\begin{array}{l}0.0120^{* *} \\
(0.0032)\end{array}$ & & $\begin{array}{l}0.0198 * * \\
(0.0052)\end{array}$ \\
\hline$C P C M_{i, j}^{k}$ & & & & & $\begin{array}{l}-0.0616 \\
(0.0633)\end{array}$ & $\begin{array}{l}-0.0440 \\
(0.0622)\end{array}$ \\
\hline $\begin{array}{l}\text { Adjusted } \\
\mathrm{R}^{2}\end{array}$ & 0.5066 & 0.5050 & 0.4756 & 0.5780 & 0.5079 & 0.6151 \\
\hline
\end{tabular}

Notes: The estimation results of equation (11) using the data under ISIC Revision 2 are presented. The sample consists of Belgium, Canada, Denmark, Finland, Italy, Japan, Netherlands, Norway, and the U.K The sample period is 1971-1994. For all specifications, both country dummy and sector dummy variables are included. Heteroskedasticity-robust standard errors (White, 1980) are provided in parentheses. ${ }^{* *}$ and $*$ indicate statistical significance at, respectively, the $1 \%$ and $5 \%$ levels. See the text for definitions of the variables. 
Table C1-4. The Results of Exchange Rate Change - Inflation Differential Covariance Regression: 9-Country Sample under the ISIC Revision 2, 1971-1994

\begin{tabular}{|c|c|c|c|c|c|c|}
\hline & \multicolumn{6}{|c|}{ Model Specifications } \\
\hline & 1 & 2 & 3 & 4 & 5 & 6 \\
\hline Distance & $\begin{array}{l}0.0000 \\
(0.0002)\end{array}$ & $\begin{array}{l}0.0003 \\
(0.0002)\end{array}$ & $\begin{array}{l}0.0002 \\
(0.0002)\end{array}$ & $\begin{array}{l}0.0003 \\
(0.0002)\end{array}$ & $\begin{array}{l}0.0002 \\
(0.0002)\end{array}$ & $\begin{array}{l}0.0002 \\
(0.0002)\end{array}$ \\
\hline Exchange & & $-0.1796 * *$ & $-0.1924 * *$ & $-0.1820^{* *}$ & $-0.1438 * *$ & $-0.1718 * *$ \\
\hline Rate & & $(0.0491)$ & $(0.0528)$ & (0.0505) & $(0.0515)$ & $(0.0556)$ \\
\hline Volatility & & & & & & \\
\hline$A P C M_{i, j}^{k}$ & & & $\begin{array}{l}-0.0021 * \\
(0.0008)\end{array}$ & & & $\begin{array}{l}-0.0025^{* *} \\
(0.0009)\end{array}$ \\
\hline$V P C M_{i, j}^{k}$ & & & & $\begin{array}{l}-0.0003 \\
(0.0007)\end{array}$ & & $\begin{array}{l}-0.0022^{*} \\
(0.0009)\end{array}$ \\
\hline$C P C M_{i, j}^{k}$ & & & & & $\begin{array}{l}-0.0334 * * \\
(0.0107)\end{array}$ & $\begin{array}{l}-0.0422 * \\
(0.0165)\end{array}$ \\
\hline $\begin{array}{l}\text { Adjusted } \\
\mathrm{R}^{2}\end{array}$ & 0.1301 & 0.1605 & 0.1797 & 0.1585 & 0.1761 & 0.2098 \\
\hline
\end{tabular}

Notes: The estimation results of equation (12) using the data under ISIC Revision 2 are presented. The sample consists of Belgium, Canada, Denmark, Finland, Italy, Japan, Netherlands, Norway, and the U.K The sample period is 1971-1994. For all specifications, both country dummy and sector dummy variables are included. Heteroskedasticity-robust standard errors (White, 1980) are provided in parentheses. ${ }^{* *}$ and $*$ indicate statistical significance at, respectively, the $1 \%$ and $5 \%$ levels. See the text for definitions of the variables. 
Table C1-5. The Results of Exchange Rate Change - Inflation Differential Covariance Regression: 9-Country Sample under the ISIC Revision 2, 1971-1994

\begin{tabular}{|c|c|c|c|c|c|c|}
\hline & \multicolumn{6}{|c|}{ Model Specifications } \\
\hline & 7 & 8 & 9 & 10 & 11 & 12 \\
\hline Distance & $\begin{array}{l}0.0004 \\
(0.0003)\end{array}$ & $\begin{array}{l}0.0003 \\
(0.0002)\end{array}$ & $\begin{array}{l}0.0001 \\
(0.0002)\end{array}$ & $\begin{array}{l}0.0004 \\
(0.0003)\end{array}$ & $\begin{array}{l}0.0002 \\
(0.0002)\end{array}$ & $\begin{array}{l}0.0002 \\
(0.0003)\end{array}$ \\
\hline Exchange & $-0.1501^{* *}$ & $-0.1673 * *$ & $-0.2197 * *$ & $-0.2182 * *$ & $-0.1658 * *$ & $-0.2541 * *$ \\
\hline $\begin{array}{l}\text { Rate } \\
\text { Volatility }\end{array}$ & $(0.0571)$ & $(0.0555)$ & $(0.0673)$ & $(0.0702)$ & $(0.0571)$ & $(0.0818)$ \\
\hline$A P C M_{i, j}^{k}$ & $\begin{array}{l}-0.0025^{* *} \\
(0.0009)\end{array}$ & $\begin{array}{l}-0.0024^{* *} \\
(0.0009)\end{array}$ & $\begin{array}{l}-0.0022^{*} \\
(0.0009)\end{array}$ & $\begin{array}{l}-0.0021^{*} \\
(0.0009)\end{array}$ & $\begin{array}{l}-0.0024^{* *} \\
(0.0009)\end{array}$ & $\begin{array}{l}-0.0019 * \\
(0.0009)\end{array}$ \\
\hline$V P C M_{i, j}^{k}$ & $\begin{array}{l}-0.0022^{*} \\
(0.0010)\end{array}$ & $\begin{array}{l}-0.0022 * \\
(0.0009)\end{array}$ & $\begin{array}{l}-0.0021^{*} \\
(0.0009)\end{array}$ & $\begin{array}{l}-0.0020^{*} \\
(0.0009)\end{array}$ & $\begin{array}{l}-0.0022^{*} \\
(0.0009)\end{array}$ & $\begin{array}{l}-0.0020^{*} \\
(0.0009)\end{array}$ \\
\hline$C P C M_{i, j}^{k}$ & $\begin{array}{l}-0.0399 * \\
(0.0074)\end{array}$ & $\begin{array}{l}-0.0407 * \\
(0.0164)\end{array}$ & $\begin{array}{l}-0.0455^{* *} \\
(0.0164)\end{array}$ & $\begin{array}{l}-0.0436^{* *} \\
(0.0164)\end{array}$ & $\begin{array}{l}-0.0421^{*} \\
(0.0166)\end{array}$ & $\begin{array}{l}-0.0473 * * \\
(0.0169)\end{array}$ \\
\hline Adjacency & $\begin{array}{l}0.0011^{*} \\
(0.0005)\end{array}$ & & & $\begin{array}{l}0.0005 \\
(0.0006)\end{array}$ & & $\begin{array}{l}-0.0011 \\
(0.0010)\end{array}$ \\
\hline Language & & $\begin{array}{l}0.0009 * \\
(0.0004)\end{array}$ & & $\begin{array}{l}0.0010^{\#} \\
(0.0005)\end{array}$ & & $\begin{array}{l}0.0017^{*} \\
(0.0006)\end{array}$ \\
\hline Sea & & & $\begin{array}{l}0.0007 \\
(0.0004)\end{array}$ & $\begin{array}{l}0.0009^{\#} \\
(0.0005)\end{array}$ & & $\begin{array}{l}0.0011^{\#} \\
(0.0005)\end{array}$ \\
\hline EEC & & & & & $\begin{array}{l}-0.0000 \\
(0.0006)\end{array}$ & $\begin{array}{l}-0.0002 \\
(0.0006)\end{array}$ \\
\hline EFTA & & & & & $\begin{array}{l}0.0012^{*} \\
(0.0006)\end{array}$ & $\begin{array}{l}0.0022^{*} \\
(0.0011)\end{array}$ \\
\hline $\begin{array}{l}\text { Adjusted } \\
\mathrm{R}^{2}\end{array}$ & 0.2148 & 0.2144 & 0.2124 & 0.2201 & 0.2103 & 0.2207 \\
\hline
\end{tabular}

Notes: The estimation results of equation (12) using the data under ISIC Revision 2 are presented. The sample consists of Belgium, Canada, Denmark, Finland, Italy, Japan, Netherlands, Norway, and the U.K The sample period is 1971-1994. For all specifications, both country dummy and sector dummy variables are included. Heteroskedasticity-robust standard errors (White, 1980) are provided in parentheses. ${ }^{* *}$ and $*$ indicate statistical significance at, respectively, the $1 \%$ and $5 \%$ levels. See the text for definitions of the variables. 
Table C2-1. The Results of the Cross-Country Relative Price Volatility Regression: 9-Country Sample under the ISIC Revision 3, 1971-1998

\begin{tabular}{|c|c|c|c|c|c|c|}
\hline & \multicolumn{6}{|c|}{ Model Specifications } \\
\hline & 1 & 2 & 3 & 4 & 5 & 6 \\
\hline Distance & $\begin{array}{l}0.0015^{*} \\
(0.0006)\end{array}$ & $\begin{array}{l}0.0002 \\
(0.0006)\end{array}$ & $\begin{array}{l}0.0000 \\
(0.0006)\end{array}$ & $\begin{array}{l}0.0002 \\
(0.0006)\end{array}$ & $\begin{array}{l}0.0003 \\
(0.0006)\end{array}$ & $\begin{array}{l}0.0002 \\
(0.0006)\end{array}$ \\
\hline Exchange & & $1.3586^{* *}$ & $1.4037 * *$ & $1.3828 * *$ & $1.3437^{* *}$ & $1.3922 * *$ \\
\hline Rate & & $(0.1429)$ & $(0.1782)$ & $(0.1415)$ & $(0.1440)$ & $(0.1804)$ \\
\hline Volatility & & & & & & \\
\hline$A P C M_{i, j}^{k}$ & & & $\begin{array}{l}-0.0035 \\
(0.0029)\end{array}$ & & & $\begin{array}{l}0.0016 \\
(0.0034)\end{array}$ \\
\hline$V P C M_{i, j}^{k}$ & & & & $\begin{array}{l}0.0083 * * \\
(0.0022)\end{array}$ & & $\begin{array}{l}0.0101 * * \\
(0.0029)\end{array}$ \\
\hline$C P C M_{i, j}^{k}$ & & & & & $\begin{array}{l}0.1097 * \\
(0.0554)\end{array}$ & $\begin{array}{l}0.1136^{*} \\
(0.0524)\end{array}$ \\
\hline $\begin{array}{l}\text { Adjusted } \\
\mathrm{R}^{2}\end{array}$ & 0.6082 & 0.6764 & 0.7152 & 0.6880 & 0.6807 & 0.7329 \\
\hline
\end{tabular}

Notes: The estimation results of equation (9) using the data under ISIC Revision 3 are presented. The sample consists of Belgium, Canada, Denmark, Finland, Italy, Japan, Netherlands, Norway, and the U.K The sample period is 1971-1998. For all specifications, both country dummy and sector dummy variables are included. Heteroskedasticity-robust standard errors (White, 1980) are provided in parentheses. ${ }^{* *}$ and $*$ indicate statistical significance at, respectively, the $1 \%$ and $5 \%$ levels. See the text for definitions of the variables. 
Table C2-2. The Results of the Cross-Country Relative Price Volatility Regression: 9-Country Sample under the ISIC Revision 3, 1971-1998

\begin{tabular}{|c|c|c|c|c|c|c|}
\hline & \multicolumn{6}{|c|}{ Model Specifications } \\
\hline & 7 & 8 & 9 & 10 & 11 & 12 \\
\hline Distance & $\begin{array}{l}0.0001 \\
(0.0007)\end{array}$ & $\begin{array}{l}0.0000 \\
(0.0006)\end{array}$ & $\begin{array}{l}0.0002 \\
(0.0006)\end{array}$ & $\begin{array}{l}0.0003 \\
(0.0007)\end{array}$ & $\begin{array}{l}-0.0007 \\
(0.0008)\end{array}$ & $\begin{array}{l}-0.0004 \\
(0.0008)\end{array}$ \\
\hline Exchange & $1.3887^{* *}$ & $1.3605^{* *}$ & $1.4505^{* *}$ & $1.4080^{* *}$ & $1.4314^{* *}$ & $1.4418^{* *}$ \\
\hline $\begin{array}{l}\text { Rate } \\
\text { Volatility }\end{array}$ & $(0.1865)$ & (0.1966) & $(0.1882)$ & (0.1995) & $(0.1743)$ & (0.1859) \\
\hline$A P C M_{i, j}^{k}$ & $\begin{array}{l}0.0016 \\
(0.0034)\end{array}$ & $\begin{array}{l}0.0016 \\
(0.0034)\end{array}$ & $\begin{array}{l}0.0015 \\
(0.0034)\end{array}$ & $\begin{array}{l}0.0015 \\
(0.0034)\end{array}$ & $\begin{array}{l}0.0014 \\
(0.0034)\end{array}$ & $\begin{array}{l}0.0014 \\
(0.0035)\end{array}$ \\
\hline$V P C M_{i, j}^{k}$ & $\begin{array}{l}0.0101^{* *} \\
(0.0029)\end{array}$ & $\begin{array}{l}0.0102 * * \\
(0.0029)\end{array}$ & $\begin{array}{l}0.0099 * * \\
(0.0029)\end{array}$ & $\begin{array}{l}0.0099 * * \\
(0.0029)\end{array}$ & $\begin{array}{l}0.0097 * * \\
(0.0029)\end{array}$ & $\begin{array}{l}0.0096 * * \\
(0.0030)\end{array}$ \\
\hline$C P C M_{i, j}^{k}$ & $\begin{array}{l}0.1134^{*} \\
(0.0530)\end{array}$ & $\begin{array}{l}0.1142 * \\
(0.0526)\end{array}$ & $\begin{array}{l}0.1111^{*} \\
(0.0526)\end{array}$ & $\begin{array}{l}0.1136 * \\
(0.0533)\end{array}$ & $\begin{array}{l}0.1227 * \\
(0.0521)\end{array}$ & $\begin{array}{l}0.12361 * \\
(0.0533)\end{array}$ \\
\hline Adjacency & $\begin{array}{l}-0.0002 \\
(0.0027)\end{array}$ & & & $\begin{array}{l}0.0021 \\
(0.0032)\end{array}$ & & $\begin{array}{l}0.0027 \\
(0.0033)\end{array}$ \\
\hline Language & & $\begin{array}{l}-0.0010 \\
(0.0014)\end{array}$ & & $\begin{array}{l}-0.0025 \\
(0.0016)\end{array}$ & & $\begin{array}{l}-0.0029 \\
(0.0019)\end{array}$ \\
\hline Sea & & & $\begin{array}{l}-0.0020 \# \\
(0.0010)\end{array}$ & $\begin{array}{l}-0.0022 * \\
(0.0011)\end{array}$ & & $\begin{array}{l}-0.0018 * \\
(0.0016)\end{array}$ \\
\hline$E E C$ & & & & & $\begin{array}{l}-0.0024 \# \\
(0.0014)\end{array}$ & $\begin{array}{l}-0.0023 \\
(0.0015)\end{array}$ \\
\hline EFTA & & & & & $\begin{array}{l}-0.0028 \\
(0.0020)\end{array}$ & $\begin{array}{l}-0.0003 \\
(0.0030)\end{array}$ \\
\hline $\begin{array}{l}\text { Adjusted } \\
\mathrm{R}^{2}\end{array}$ & 0.7319 & 0.7323 & 0.7348 & 0.7340 & 0.7350 & 0.7342 \\
\hline
\end{tabular}

Notes: The estimation results of equation (9) using the data under ISIC Revision 3 are presented. The sample consists of Belgium, Canada, Denmark, Finland, Italy, Japan, Netherlands, Norway, and the U.K The sample period is 1971-1998. For all specifications, both country dummy and sector dummy variables are included. Heteroskedasticity-robust standard errors (White, 1980) are provided in parentheses. ${ }^{* *}$ and * indicate statistical significance at, respectively, the $1 \%$ and $5 \%$ levels. See the text for definitions of the variables. 
Table C2-3. The Results of the Inflation Differential Variability Regression: 9-Country Sample, under the ISIC Revision 3, 1971-1998

\begin{tabular}{|c|c|c|c|c|c|c|}
\hline & \multicolumn{6}{|c|}{ Model Specifications } \\
\hline & 1 & 2 & 3 & 4 & 5 & 6 \\
\hline Distance & $\begin{array}{l}0.0006 \\
(0.0004)\end{array}$ & $\begin{array}{l}0.0004 \\
(0.0004)\end{array}$ & $\begin{array}{l}0.0002 \\
(0.0003)\end{array}$ & $\begin{array}{l}0.0004 \\
(0.0004)\end{array}$ & $\begin{array}{l}0.0004 \\
(0.0004)\end{array}$ & $\begin{array}{l}0.0004 \\
(0.0004)\end{array}$ \\
\hline Exchange & & $0.2108 \#$ & -0.0065 & $0.2374 *$ & $0.2089 \#$ & $0.2225 \#$ \\
\hline $\begin{array}{l}\text { Rate } \\
\text { Volatility }\end{array}$ & & $(0.1242)$ & (0.0355) & (0.1206) & & \\
\hline$A P C M_{i, j}^{k}$ & & & $\begin{array}{l}-0.0083^{* *} \\
(0.0019)\end{array}$ & & & $\begin{array}{l}-0.0042 \# \\
(0.0022)\end{array}$ \\
\hline$V P C M_{i, j}^{k}$ & & & & $\begin{array}{l}0.0091^{* *} \\
(0.0018)\end{array}$ & & $\begin{array}{l}0.0080^{* *} \\
(0.0021)\end{array}$ \\
\hline$C P C M_{i, j}^{k}$ & & & & & $\begin{array}{l}0.0142 \\
(0.0504)\end{array}$ & $\begin{array}{l}-0.0014 \\
(0.0456)\end{array}$ \\
\hline $\begin{array}{l}\text { Adjusted } \\
\mathrm{R}^{2}\end{array}$ & 0.5835 & 0.5856 & 0.7106 & 0.6147 & 0.5846 & 0.7288 \\
\hline
\end{tabular}

Notes: The estimation results of equation (11) using the data under ISIC Revision 2 are presented. The sample consists of Belgium, Canada, Denmark, Finland, Italy, Japan, Netherlands, Norway, and the U.K The sample period is 1971-1998. For all specifications, both country dummy and sector dummy variables are included. Heteroskedasticity-robust standard errors (White, 1980) are provided in parentheses. ${ }^{* *}$ and $*$ indicate statistical significance at, respectively, the $1 \%$ and $5 \%$ levels. See the text for definitions of the variables. 
Table C2-4. The Results of Exchange Rate Change - Inflation Differential Covariance Regression: 9-Country Sample under the ISIC Revision 3, 1971-1998

\begin{tabular}{|c|c|c|c|c|c|c|}
\hline & \multicolumn{6}{|c|}{ Model Specifications } \\
\hline & 1 & 2 & 3 & 4 & 5 & 6 \\
\hline Distance & $\begin{array}{l}0.0000 \\
(0.0002)\end{array}$ & $\begin{array}{l}0.0001 \\
(0.0002)\end{array}$ & $\begin{array}{l}0.0001 \\
(0.0002)\end{array}$ & $\begin{array}{l}0.0001 \\
(0.0003)\end{array}$ & $\begin{array}{l}0.0000 \\
(0.0002)\end{array}$ & $\begin{array}{l}0.0001 \\
(0.0002)\end{array}$ \\
\hline $\begin{array}{l}\text { Exchange } \\
\text { Rate } \\
\text { Volatility }\end{array}$ & & $\begin{array}{l}-0.0738 \\
(0.0448)\end{array}$ & $\begin{array}{l}-0.1071 \# \\
(0.0564)\end{array}$ & $\begin{array}{l}-0.0726 \\
(0.0450)\end{array}$ & $\begin{array}{l}-0.0674 \\
(0.0448)\end{array}$ & $\begin{array}{l}-0.0848 \\
(0.0571)\end{array}$ \\
\hline$A P C M_{i, j}^{k}$ & & & $\begin{array}{l}-0.0024^{* *} \\
(0.0008)\end{array}$ & & & $\begin{array}{l}-0.0029 * * \\
(0.0011)\end{array}$ \\
\hline$V P C M_{i, j}^{k}$ & & & & $\begin{array}{l}0.0004 \\
(0.0005)\end{array}$ & & $\begin{array}{l}-0.0010 \\
(0.0010)\end{array}$ \\
\hline$C P C M_{i, j}^{k}$ & & & & & $\begin{array}{l}-0.0477 * \\
(0.0160)\end{array}$ & $\begin{array}{l}-0.0575^{* *} \\
(0.0172)\end{array}$ \\
\hline $\begin{array}{l}\text { Adjusted } \\
\mathrm{R}^{2}\end{array}$ & 0.1336 & 0.1373 & 0.1524 & 0.1356 & 0.1646 & 0.1935 \\
\hline
\end{tabular}

Notes: The estimation results of equation (12) using the data under ISIC Revision 2 are presented. The sample consists of Belgium, Canada, Denmark, Finland, Italy, Japan, Netherlands, Norway, and the U.K The sample period is 1971-1998. For all specifications, both country dummy and sector dummy variables are included. Heteroskedasticity-robust standard errors (White, 1980) are provided in parentheses. $* *$ and * indicate statistical significance at, respectively, the $1 \%$ and $5 \%$ levels. See the text for definitions of the variables. 
Table C2-5. The Results of Exchange Rate Change - Inflation Differential Covariance Regression; 9-Country Sample under the ISIC Revision 3, 1971-1998

\begin{tabular}{|c|c|c|c|c|c|c|}
\hline & \multicolumn{6}{|c|}{ Model Specifications } \\
\hline & 7 & 8 & 9 & 10 & 11 & 12 \\
\hline Distance & $\begin{array}{l}0.0001 \\
(0.0002)\end{array}$ & $\begin{array}{l}0.0001 \\
(0.0002)\end{array}$ & $\begin{array}{l}0.0000 \\
(0.0002)\end{array}$ & $\begin{array}{l}0.0000 \\
(0.0002)\end{array}$ & $\begin{array}{l}0.0004 \# \\
(0.0002)\end{array}$ & $\begin{array}{l}0.0001 \\
(0.0002)\end{array}$ \\
\hline Exchange & -0.0821 & -0.0702 & $-0.1246^{*}$ & $-0.1019 \#$ & $-0.0964 \#$ & $-0.1246^{*}$ \\
\hline $\begin{array}{l}\text { Rate } \\
\text { Volatility }\end{array}$ & $(0.0587)$ & $(0.0618)$ & $(0.0580)$ & $(0.0612)$ & $(0.0543)$ & $(0.0570)$ \\
\hline$A P C M_{i, j}^{k}$ & $\begin{array}{l}-0.0029 * * \\
(0.0011)\end{array}$ & $\begin{array}{l}-0.0029 * * \\
(0.0011)\end{array}$ & $\begin{array}{l}-0.0028^{* *} \\
(0.0010)\end{array}$ & $\begin{array}{l}-0.0028^{* *} \\
(0.0011)\end{array}$ & $\begin{array}{l}-0.0029 * \\
(0.0011)\end{array}$ & $\begin{array}{l}-0.0028^{*} \\
(0.0011)\end{array}$ \\
\hline$V P C M_{i, j}^{k}$ & $\begin{array}{l}-0.0010 \\
(0.0010)\end{array}$ & $\begin{array}{l}-0.0010 \\
(0.0010)\end{array}$ & $\begin{array}{l}-0.0008 \\
(0.0009)\end{array}$ & $\begin{array}{l}-0.0008 \\
(0.0010)\end{array}$ & $\begin{array}{l}-0.0009 \\
(0.0010)\end{array}$ & $\begin{array}{l}-0.0007 \\
(0.0010)\end{array}$ \\
\hline$C P C M_{i, j}^{k}$ & $\begin{array}{l}-0.0574 * * \\
(0.0172)\end{array}$ & $\begin{array}{l}-0.0578^{* *} \\
(0.0172)\end{array}$ & $\begin{array}{l}-0.0558^{* *} \\
(0.0165)\end{array}$ & $\begin{array}{l}-0.0570^{* *} \\
(0.0167)\end{array}$ & $\begin{array}{l}-0.0606 * * \\
(0.0166)\end{array}$ & $\begin{array}{l}-0.0595 * * \\
(0.0165)\end{array}$ \\
\hline Adjacency & $\begin{array}{l}0.0002 \\
(0.0002)\end{array}$ & & & $\begin{array}{l}-0.0009 \\
(0.0008)\end{array}$ & & $\begin{array}{l}-0.0014 \\
(0.0009)\end{array}$ \\
\hline Language & & $\begin{array}{l}0.0004 \\
(0.0004)\end{array}$ & & $\begin{array}{l}0.0012^{*} \\
(0.0005)\end{array}$ & & $\begin{array}{l}0.0015^{*} \\
(0.0006)\end{array}$ \\
\hline Sea & & & $\begin{array}{l}0.0013^{* *} \\
(0.0003)\end{array}$ & $\begin{array}{l}0.0015^{* *} \\
(0.0003)\end{array}$ & & $\begin{array}{l}0.0017 * * \\
(0.0005)\end{array}$ \\
\hline EEC & & & & & $\begin{array}{l}0.0008^{*} \\
(0.0004)\end{array}$ & $\begin{array}{l}0.0006 \\
(0.0004)\end{array}$ \\
\hline EFTA & & & & & $\begin{array}{l}0.0013^{*} \\
(0.0005)\end{array}$ & $\begin{array}{l}-0.0009 \\
(0.0008)\end{array}$ \\
\hline $\begin{array}{l}\text { Adjusted } \\
\mathrm{R}^{2}\end{array}$ & 0.1907 & 0.1930 & 0.2327 & 0.2372 & 0.2074 & 0.2399 \\
\hline
\end{tabular}

Notes: The estimation results of equation (12) using the data under ISIC Revision 2 are presented. The sample consists of Belgium, Canada, Denmark, Finland, Italy, Japan, Netherlands, Norway, and the U.K The sample period is 1971-1998. For all specifications, both country dummy and sector dummy variables are included. Heteroskedasticity-robust standard errors (White, 1980) are provided in parentheses. ${ }^{* *}$ and $*$ indicate statistical significance at, respectively, the $1 \%$ and $5 \%$ levels. See the text for definitions of the variables. 


\title{
CESifo Working Paper Series
}

\author{
(for full list see www.cesifo.de)
}

1390 James J. Heckman and Dimitriy V. Masterov, Skill Policies for Scotland, January 2005

1391 Emma Galli \& Fabio Padovano, Sustainability and Determinants of Italian Public Deficits before and after Maastricht, January 2005

1392 Angel de la Fuente and Juan Francisco Jimeno, The Private and Fiscal Returns to Schooling and the Effect of Public Policies on Private Incentives to Invest in Education: A General Framework and Some Results for the EU, January 2005

1393 Juan C. Conesa and Carlos Garriga, Optimal Response to a Demographic Shock, January 2005

1394 Christian Gollier, Optimal Portfolio Management for Individual Pension Plans, February 2005

1395 Ruslan Lukach, Joseph Plasmans and Peter M. Kort, Innovation Strategies in a Competitive Dynamic Setting, February 2005

1396 Gebhard Kirchgässner, (Why) Are Economists Different?, February 2005

1397 Marko Köthenbürger, Panu Poutvaara and Paola Profeta, Why are More Redistributive Social Security Systems Smaller? A Median Voter Approach, February 2005

1398 Gabrielle Demange, Free Choice of Unfunded Systems: A First Assessment, February 2005

1399 Carlos Fonseca Marinheiro, Sustainability of Portuguese Fiscal Policy in Historical Perspective, February 2005

1400 Roel M. W. J. Beetsma and Koen Vermeylen, The Effect of Monetary Unification on Public Debt and its Real Return, February 2005

1401 Frank Asche, Petter Osmundsen and Maria Sandsmark, Is It All Oil?, February 2005

1402 Giacomo Corneo, Media Capture in a Democracy: The Role of Wealth Concentration, February 2005

1403 A. Lans Bovenberg and Thijs Knaap, Ageing, Funded Pensions and the Dutch Economy, February 2005

1404 Thiess Büttner, The Incentive Effect of Fiscal Equalization Transfers on Tax Policy, February 2005

1405 Luisa Fuster, Ayşe İmrohoroğlu and Selahattin İmrohoroğlu, Personal Security Accounts and Mandatory Annuitization in a Dynastic Framework, February 2005 
1406 Peter Claeys, Policy Mix and Debt Sustainability: Evidence from Fiscal Policy Rules, February 2005

1407 James M. Malcomson, Supplier Discretion over Provision: Theory and an Application to Medical Care, February 2005

1408 Thorvaldur Gylfason, Interview with Assar Lindbeck, February 2005

1409 Christian Gollier, Some Aspects of the Economics of Catastrophe Risk Insurance, February 2005

1410 Gebhard Kirchgässner, The Weak Rationality Principle in Economics, February 2005

1411 Carlos José Fonseca Marinheiro, Has the Stability and Growth Pact Stabilised? Evidence from a Panel of 12 European Countries and Some Implications for the Reform of the Pact, February 2005

1412 Petter Osmundsen, Frank Asche, Bård Misund and Klaus Mohn, Valuation of International Oil Companies -The RoACE Era, February 2005

1413 Gil S. Epstein and Shmuel Nitzan, Lobbying and Compromise, February 2005

1414 Marcel F. M. Canoy, Jan C. van Ours and Frederick van der Ploeg, The Economics of Books, February 2005

1415 Eric A. Hanushek and Ludger Wößmann, Does Educational Tracking Affect Performance and Inequality? Differences-in-Differences Evidence across Countries, February 2005

1416 George Kapetanios and M. Hashem Pesaran, Alternative Approaches to Estimation and Inference in Large Multifactor Panels: Small Sample Results with an Application to Modelling of Asset Returns, February 2005

1417 Samuel Mühlemann, Jürg Schweri, Rainer Winkelmann and Stefan C. Wolter, A Structural Model of Demand for Apprentices. February 2005

1418 Giorgio Brunello and Lorenzo Rocco, Educational Standards in Private and Public Schools, February 2005

1419 Alex Bryson, Lorenzo Cappellari and Claudio Lucifora, Why so Unhappy? The Effects of Unionisation on Job Satisfaction, March 2005

1420 Annalisa Luporini, Relative Performance Evaluation in a Multi-Plant Firm, March 2005

1421 Giorgio Bellettini and Carlotta Berti Ceroni, When the Union Hurts the Workers: A Positive Analysis of Immigration Policy, March 2005

1422 Pieter Gautier, Michael Svarer and Coen Teulings, Marriage and the City, March 2005 
1423 Ingrid Ott and Stephen J. Turnovsky, Excludable and Non-Excludable Public Inputs: Consequences for Economic Growth, March 2005

1424 Frederick van der Ploeg, Back to Keynes?, March 2005

1425 Stephane Dees, Filippo di Mauro, M. Hashem Pesaran and L. Vanessa Smith, Exploring the International Linkages of the Euro Area: a Global VAR Analysis, March 2005

1426 Hans Pitlik, Friedrich Schneider and Harald Strotmann, Legislative Malapportionment and the Politicization of Germany's Intergovernmental Transfer System, March 2005

1427 Konstantinos Angelopoulos and Apostolis Philippopoulos, The Role of Government in Anti-Social Redistributive Activities, March 2005

1428 Ansgar Belke and Daniel Gros, Asymmetries in the Trans-Atlantic Monetary Policy Relationship: Does the ECB follow the Fed?, March 2005

1429 Sören Blomquist and Luca Micheletto, Optimal Redistributive Taxation when Government's and Agents' Preferences Differ, March 2005

1430 Olof Åslund and Peter Fredriksson, Ethnic Enclaves and Welfare Cultures - QuasiExperimental Evidence, March 2005

1431 Paul De Grauwe, Roberto Dieci and Marianna Grimaldi, Fundamental and NonFundamental Equilibria in the Foreign Exchange Market. A Behavioural Finance Framework, March 2005

1432 Peter Egger, Stefan Gruber, Mario Larch and Michael Pfaffermayr, Knowledge-Capital Meets New Economic Geography, March 2005

1433 George Economides and Apostolis Philippopoulos, Should Green Governments Give Priority to Environmental Policies over Growth-Enhancing Policies?, March 2005

1434 George W. Evans and Seppo Honkapohja, An Interview with Thomas J. Sargent, March 2005

1435 Helge Berger and Volker Nitsch, Zooming Out: The Trade Effect of the Euro in Historical Perspective, March 2005

1436 Marc-Andreas Muendler, Rational Information Choice in Financial Market Equilibrium, March 2005

1437 Martin Kolmar and Volker Meier, Intra-Generational Externalities and InterGenerational Transfers, March 2005

1438 M. Hashem Pesaran and Takashi Yamagata, Testing Slope Homogeneity in Large Panels, March 2005

1439 Gjermund Nese and Odd Rune Straume, Industry Concentration and Strategic Trade Policy in Successive Oligopoly, April 2005 
1440 Tomer Blumkin and Efraim Sadka, A Case for Taxing Education, April 2005

1441 John Whalley, Globalization and Values, April 2005

1442 Denise L. Mauzerall, Babar Sultan, Namsoug Kim and David F. Bradford, Charging $\mathrm{NO}_{x}$ Emitters for Health Damages: An Exploratory Analysis, April 2005

1443 Britta Hamburg, Mathias Hoffmann and Joachim Keller, Consumption, Wealth and Business Cycles in Germany, April 2005

1444 Kohei Daido and Hideshi Itoh, The Pygmalion Effect: An Agency Model with Reference Dependent Preferences, April 2005

1445 John Whalley, Rationality, Irrationality and Economic Cognition, April 2005

1446 Henning Bohn, The Sustainability of Fiscal Policy in the United States, April 2005

1447 Torben M. Andersen, Is there a Role for an Active Fiscal Stabilization Policy? April 2005

1448 Hans Gersbach and Hans Haller, Bargaining Power and Equilibrium Consumption, April 2005

1449 Jerome L. Stein, The Transition Economies: A NATREX Evaluation of Research, April 2005

1450 Raymond Riezman, John Whalley and Shunming Zhang, Metrics Capturing the Degree to which Individual Economies are Globalized, April 2005

1451 Romain Ranciere, Aaron Tornell and Frank Westermann, Systemic Crises and Growth, April 2005

1452 Plutarchos Sakellaris and Focco W. Vijselaar, Capital Quality Improvement and the Sources of Growth in the Euro Area, April 2005

1453 Kevin Milligan and Michael Smart, Regional Grants as Pork Barrel Politics, April 2005

1454 Panu Poutvaara and Andreas Wagener, To Draft or not to Draft? Efficiency, Generational Incidence, and Political Economy of Military Conscription, April 2005

1455 Maurice Kugler and Hillel Rapoport, Skilled Emigration, Business Networks and Foreign Direct Investment, April 2005

1456 Yin-Wong Cheung and Eiji Fujii, Cross-Country Relative Price Volatility: Effects of Market Structure, April 2005 